\title{
Regional and seasonal radiative forcing by perturbations to aerosol and ozone precursor emissions
}

\author{
Nicolas Bellouin ${ }^{1}$, Laura Baker ${ }^{1}$, Øivind Hodnebrog $^{2}$, Dirk Olivié $^{3}$, Ribu Cherian $^{4}$, Claire Macintosh $^{1}$, \\ Bjørn Samset $^{2}$, Anna Esteve ${ }^{1, a}$, Borgar Aamaas ${ }^{2}$, Johannes Quaas ${ }^{4}$, and Gunnar Myhre ${ }^{2}$ \\ ${ }^{1}$ Department of Meteorology, University of Reading, Reading, UK \\ ${ }^{2}$ Center for International Climate and Environmental Research, Oslo (CICERO), Oslo, Norway \\ ${ }^{3}$ Norwegian Meteorological Institute, Oslo, Norway \\ ${ }^{4}$ Institute for Meteorology, Universitat Leipzig, Leipzig, Germany \\ ${ }^{a}$ now at: University of Valencia, Valencia, Spain \\ Correspondence to: Nicolas Bellouin (n.bellouin@ reading.ac.uk)
}

Received: 8 April 2016 - Published in Atmos. Chem. Phys. Discuss.: 27 April 2016

Revised: 30 September 2016 - Accepted: 17 October 2016 - Published: 9 November 2016

\begin{abstract}
Predictions of temperature and precipitation responses to changes in the anthropogenic emissions of climate forcers require the quantification of the radiative forcing exerted by those changes. This task is particularly difficult for near-term climate forcers like aerosols, methane, and ozone precursors because their short atmospheric lifetimes cause regionally and temporally inhomogeneous radiative forcings. This study quantifies specific radiative forcing, defined as the radiative forcing per unit change in mass emitted, for eight near-term climate forcers as a function of their source regions and the season of emission by using dedicated simulations by four general circulation and chemistry-transport models. Although differences in the representation of atmospheric chemistry and radiative processes in different models impede the creation of a uniform dataset, four distinct findings can be highlighted. Firstly, specific radiative forcing for sulfur dioxide and organic carbon are stronger when aerosolcloud interactions are taken into account. Secondly, there is a lack of agreement on the sign of the specific radiative forcing of volatile organic compound perturbations, suggesting they are better avoided in climate mitigation strategies. Thirdly, the strong seasonalities of the specific radiative forcing of most forcers allow strategies to minimise positive radiative forcing based on the timing of emissions. Finally, European and shipping emissions exert stronger aerosol specific radiative forcings compared to East Asia where the baseline is more polluted. This study can therefore form the basis for further refining climate mitigation options based on regional
\end{abstract}

and seasonal controls on emissions. For example, reducing summertime emissions of black carbon and wintertime emissions of sulfur dioxide in the more polluted regions is a possible way to improve air quality without weakening the negative radiative forcing of aerosols.

\section{Introduction}

Human activities have profoundly modified the composition of the atmosphere by increasing the concentrations of long-lived greenhouse gases, such as carbon dioxide or chlorofluorocarbons, and medium- to short-lived species, such as methane $\left(\mathrm{CH}_{4}\right)$, tropospheric ozone, and aerosols. Once in the atmosphere, those species perturb the energy budget of the Earth, exerting a radiative forcing (RF) of the climate system by various mechanisms, namely greenhouse gas and ozone absorption of long-wave radiation, and ozone absorption and aerosol-radiation interactions (here denoted ari following Boucher et al., 2013) in the short-wave spectrum. Changes in aerosol concentrations also translate in aerosolcloud interactions (aci) through changes in the number of cloud condensation nuclei, modifying the radiative properties and life cycle of clouds. In addition, aerosols that absorb short-wave radiation, such as mineral dust and black carbon (BC) aerosols, change the surface albedo when depositing on snow or ice. The tight interactions between gaseous and aerosol species add components to the RF caused by com- 
plex feedbacks of one species onto another (von Schneidemesser et al., 2015; Fiore et al., 2015). For example, changes in methane concentrations trigger changes in tropospheric ozone, which exert primary-mode ozone RF (Prather, 1996). Moreover, the hydroxyl radical OH links the atmospheric chemistry of ozone and the oxidation of aerosol gaseous precursors, and Shindell et al. (2009) found sizeable impacts of nitrogen oxides $\left(\mathrm{NO}_{x}\right)$, carbon monoxide $(\mathrm{CO})$, and $\mathrm{CH}_{4}$ emissions on aerosol formation in global simulations of atmospheric chemistry.

There is also complexity in the concept of RF. In its traditional definition of stratospherically adjusted RF, surface and tropospheric conditions are held fixed to their unperturbed state, but stratospheric temperatures are allowed to adjust. The fifth assessment report of the Intergovernmental Panel on Climate Change (IPCC) has recently formalised a new definition, called effective RF (ERF; Boucher et al., 2013; Myhre et al., 2013a), which also includes rapid adjustments to the tropospheric state. Those rapid adjustments occur on shorter timescales than deep ocean and sea-ice changes and include such processes as the change in cloud cover that follows the local atmospheric warming caused by aerosol absorption of short-wave radiation, the change in cloud cover due to aerosol-driven changes in precipitation efficiency, the increased spring melting that follows BC deposition on snow, or the change in cloud cover that immediately follows changes in thermodynamic profiles in response to an increase in carbon dioxide concentrations. Because ERF includes rapid adjustments, it is a better indicator of the eventual surface temperature response than RF, although an additional efficacy may be needed to account for the ability of ERF patterns predominantly located in the Northern Hemisphere to cause more rapid land surface temperature responses (Shindell, 2014). Both stratospherically adjusted and effective RF exclude the radiative impact of large-scale changes in sea-surface temperatures, which are part of the climate response.

Climate change mitigation options aim to eventually reduce and suppress the positive industrial-era ERF currently exerted on the Earth's energy budget by human activities. A difficulty in that task is that the basket of species emitted by a given sector of activity changes in response to policies and technological advances (e.g. Smith et al., 2013). To compare the climate impact of the emissions of different species while allowing for changes in their emission rates, one therefore requires the knowledge of the RF exerted per change in unit mass emission rate, hereafter called specific RF (SRF) and given in $\mathrm{mW} \mathrm{m}^{-2}\left(\mathrm{Tg} \mathrm{yr}^{-1}\right)^{-1}$. Combining the SRF of a species with its lifetime produces such climate metrics as the global warming potential or the global temperature change potential (e.g. Shine et al., 2005). In the past, the available literature has been used in a rather ad hoc way to quantify SRF. Table 1 summarises estimates from five previous multimodel studies. Bond et al. (2013), Myhre et al. (2013b), Shindell et al. (2013), and Stevenson et al. (2013) estimate SRF for industrial-era global emission changes. The SRFs from Fry (2012) and Yu et al. (2013) are based on $20 \%$ reductions in the emissions of four regions. Table 1 also shows results for the present study to allow for an easy comparison; those results are discussed in Sect. 4.

All studies agree on the sign of the SRF of individual species. $\mathrm{BC}$ aerosols, methane, $\mathrm{CO}$, and volatile organic compounds (VOCs) exert positive SRFs, which lead to a gain in energy for the climate system when emissions are increased. In contrast, sulfate, organic carbon (OC), and nitrate aerosols, as well as nitrogen oxides $\left(\mathrm{NO}_{x}\right)$, exert negative SRFs. According to those studies, BC exerts the strongest SRF of all near-term climate forcers (NTCFs), in absolute values. Its SRF is an order of magnitude larger than that of the other aerosol species. The SRF of nitrogen oxides is the strongest of the ozone precursors, being for example about 16 times larger than and of opposite sign to $\mathrm{CO}$ SRF. The strength of the SRF of a given NTCF is, however, only one aspect of its climate impact; the strength of anthropogenic emission rates also matters. Therefore, the strong SRFs of $\mathrm{BC}$ and $\mathrm{NO}_{x}$ have to be considered in the context of their small emission rates relative to other precursors like sulfur dioxide $\left(\mathrm{SO}_{2}\right)$ and $\mathrm{CO}$. Regionally for ozone precursor perturbations, Fry (2012) find that South Asia exerts the strongest SRF for $\mathrm{NO}_{x}$ and VOC perturbations, while $\mathrm{CO}$ perturbations exhibit little regional dependence. Aerosol contributions to net ozone precursor SRFs vary in sign and magnitude among models as well as regionally. For aerosol perturbations, Yu et al. (2013) find that East Asian $\mathrm{SO}_{2}$ emissions exert an SRF that is only $75 \%$ of that by European emissions, a smaller value attributed to a limitation in sulfur-cycle oxidants over East Asia, which suppresses conversion of $\mathrm{SO}_{2}$ to sulfate aerosols in that region. Furthermore, their estimate of BC SRF from European emissions is $30 \%$ stronger than that of other regions, a result attributed to the geographical extent of European aerosol transport, which covers in particular the bright surfaces of the Arctic and Sahara, where BC aerosols exert a strong positive RF.

The five studies listed in Table 1 report a sizeable amount of diversity in SRF estimates among models. That diversity reflects different aerosol optical properties (Myhre et al., 2013b) and vertical distributions (Samset et al., 2013), differences in cloud distributions, surface properties, and radiative transfer (Stier et al., 2013; Randles et al., 2013; Stevenson et al., 2013), large differences in the parameterised sensitivity of cloud albedo to aerosol changes (Quaas et al., 2009), and differences in unperturbed ozone and aerosol levels (Stevenson et al., 2013; Carslaw et al., 2013). Faced with model diversity, Myhre et al. (2013b) choose to include all models in their best estimates while Shindell et al. (2013) choose to select the models best able to represent present-day aerosol distributions and recent trends. Bond et al. (2013) scale modelled RF towards stronger values mainly through increases in emissions to account for a perceived low bias in simulated 
Table 1. Specific radiative forcing (SRF), in $\mathrm{m} \mathrm{Wm}^{-2}\left(\mathrm{Tg} \mathrm{yr}^{-1}\right)^{-1}$, of near-term climate forcers, as estimated by scientific assessments and multi-model intercomparisons. Numbers shown are median and full range for all studies, except for Bond et al. (2013), in which best estimate and $90 \%$ confidence range are given; Yu et al. (2013), in which mean and standard deviation are given; Fry (2012), in which only the best estimate is available; this study, in which average and full range are given. Black carbon (BC) and organic carbon (OC) aerosols are for fossil-fuel and biofuel sources only, except for Bond et al. (2013), in which also biomass-burning sources are included. For aerosols, the radiative forcing is for aerosol-radiation interactions (ari) only, except for the estimate by Bond et al. (2013) denoted "All", which also includes aerosol-cloud and aerosol-surface interactions, and for estimates by this study, which also include aerosol-cloud interactions (aci).

\begin{tabular}{|c|c|c|c|c|}
\hline $\begin{array}{l}\text { Emitted } \\
\text { compound }\end{array}$ & $\begin{array}{l}\text { Climate } \\
\text { forcer }\end{array}$ & Reference & Method & $\begin{array}{l}\text { SRF } \\
\left(\mathrm{mW} \mathrm{m}^{-2}\left(\mathrm{Tg} \mathrm{yr}^{-1}\right)^{-1}\right)\end{array}$ \\
\hline \multirow[t]{4}{*}{$\mathrm{SO}_{2}$} & \multirow[t]{4}{*}{$\mathrm{SO}_{4}$} & Myhre et al. (2013b) & AeroCom, 15 models, ari only & $-3.5(-5.5$ to -1.5$)$ \\
\hline & & Shindell et al. (2013) & ACCMIP, 9 models, ari only & $-4.3(-6.4$ to -2.0$)$ \\
\hline & & Yu et al. (2013) & HTAP, 8 models, 4 source regions, ari only & $\begin{array}{l}-2.9 \pm 0.8 \text { to }-3.9 \pm 0.8 \\
\text { depending on region }\end{array}$ \\
\hline & & This study & ECLIPSE, 3 models, 3 source regions, 2 seasons, ari +aci & $\begin{array}{l}-3.1 \text { to }-10.7(-1.9 \text { to }-17.7) \\
\text { depending on region }\end{array}$ \\
\hline \multirow[t]{4}{*}{$\mathrm{OC}$} & \multirow[t]{4}{*}{$\mathrm{OC}$} & Myhre et al. (2013b) & AeroCom, 15 models, ari only & $-3.8(-7.6$ to -1.3$)$ \\
\hline & & Shindell et al. (2013) & ACCMIP, 4 models, ari only & $-3.8(-10.1$ to -1.3$)$ \\
\hline & & Yu et al. (2013) & HTAP, 8 models, 4 source regions, ari only & $\begin{array}{l}-3.7 \pm 1.8 \text { to }-4.4 \pm 1.7 \\
\text { depending on region }\end{array}$ \\
\hline & & This study & ECLIPSE, 3 models, 3 source regions, 2 seasons, ari + aci & $\begin{array}{l}-4.4 \text { to }-22.5(+1.2 \text { to }-32.5) \\
\text { depending on region }\end{array}$ \\
\hline \multirow[t]{6}{*}{$\mathrm{BC}$} & \multirow[t]{6}{*}{$\mathrm{BC}$} & Bond et al. (2013) & Assessment of models with observational constraints, ari only & $+51.1(+6.5$ to +90.6$)$ \\
\hline & & Bond et al. (2013) & $\begin{array}{l}\text { Assessment of models with observational constraints, } \\
\text { all RF mechanisms }\end{array}$ & $+74.3(+12.3$ to +181.8$)$ \\
\hline & & Myhre et al. (2013b) & AeroCom, 15 models, ari only & $+45.3(+15.1$ to +75.6$)$ \\
\hline & & Shindell et al. (2013) & ACCMIP, 5 models, ari only & $+50.4(+35.3$ to +95.7$)$ \\
\hline & & Yu et al. (2013) & HTAP, 8 models, 4 source regions, ari only & $\begin{array}{l}+25.3 \pm 14.6 \text { to }+37.4 \pm 19.3 \\
\text { depending on region }\end{array}$ \\
\hline & & This study & $\begin{array}{l}\text { ECLIPSE, } 4 \text { models, } 3 \text { source regions, } 2 \text { seasons, ari+aci+deposition } \\
\text { on snow and rapid adjustments from the semi-direct effect }\end{array}$ & $\begin{array}{l}+28.7 \text { to }+69.7(+9.8 \text { to }+101.1) \\
\text { depending on region }\end{array}$ \\
\hline \multirow[t]{2}{*}{$\mathrm{NH}_{3}$} & \multirow[t]{2}{*}{$\mathrm{NO}_{3}$} & Myhre et al. (2013b) & AeroCom, 5 models, ari only & $-3.9(-13.3$ to -1.0$)$ \\
\hline & & This study & ECLIPSE, 1 model, 3 source regions, 2 seasons, ari+aci & $\begin{array}{l}-0.5 \text { to }-1.4 \\
\text { depending on region }\end{array}$ \\
\hline \multirow[t]{4}{*}{$\mathrm{CH}_{4}$} & \multirow[t]{2}{*}{$\mathrm{CH}_{4}$} & Stevenson et al. (2013) & ACCMIP, 6 models & $+2.2(+1.8$ to +3.0$)$ \\
\hline & & This study & ECLIPSE, 3 models, 3 source regions & $+1.5(+1.2$ to +2.0$)$ \\
\hline & \multirow[t]{2}{*}{$\mathrm{O}_{3}$} & Stevenson et al. (2013) & ACCMIP, 6 models & $+0.7(+0.5$ to +1.0$)$ \\
\hline & & This study & ECLIPSE, 3 models, 3 source regions & $+0.5(+0.4$ to +0.7$)$ \\
\hline \multirow[t]{8}{*}{$\mathrm{NO}_{x}$} & \multirow[t]{3}{*}{$\mathrm{CH}_{4}$} & Fry (2012) & HTAP, 11 models, 4 sources regions & $\begin{array}{l}-1.8 \text { to }-5.0 \\
\text { depending on region }\end{array}$ \\
\hline & & Stevenson et al. (2013) & ACCMIP, 6 models & $-5.5(-7.4$ to -4.2$)$ \\
\hline & & This study & ECLIPSE, 3 models, 3 source regions, includes primary-mode $\mathrm{O}_{3}$ & $\begin{array}{l}-0.4 \text { to }-2.1(-2.6 \text { to }-2.5) \\
\text { depending on region }\end{array}$ \\
\hline & \multirow[t]{3}{*}{$\mathrm{O}_{3}$} & Fry (2012) & HTAP, 11 models, 4 sources regions & $\begin{array}{l}+0.8 \text { to }+3.9 \\
\text { depending on region }\end{array}$ \\
\hline & & Stevenson et al. (2013) & ACCMIP, 6 models & $+1.9(+1.7$ to +3.3$)$ \\
\hline & & This study & ECLIPSE, 3 models, 3 source regions & $\begin{array}{l}+0.1 \text { to }+1.4(+0.1 \text { to }+1.5) \\
\text { depending on region }\end{array}$ \\
\hline & \multirow[t]{2}{*}{ Aerosols } & Fry (2012) & HTAP, 11 models, 4 source regions, sulfate ari only & $\begin{array}{l}-0.5 \text { to }+0.2 \\
\text { depending on region }\end{array}$ \\
\hline & & This study & ECLIPSE, 3 models, 3 source regions, ari+aci & $\begin{array}{l}-0.3 \text { to }-0.8(-1.2 \text { to }+0.2) \\
\text { depending on region }\end{array}$ \\
\hline \multirow[t]{8}{*}{$\mathrm{CO}$} & \multirow[t]{3}{*}{$\mathrm{CH}_{4}$} & Fry (2012) & HTAP, 11 models, 4 source regions & $\begin{array}{l}+0.08 \text { to }+0.10 \\
\text { depending on region }\end{array}$ \\
\hline & & Stevenson et al. (2013) & ACCMIP, 6 models & $+0.11(+0.07$ to +0.13$)$ \\
\hline & & This study & ECLIPSE, 3 models, 3 source regions, includes primary-mode $\mathrm{O}_{3}$ & $\begin{array}{l}+0.12 \text { to }+0.15(+0.08 \text { to }+0.20) \\
\text { depending on region }\end{array}$ \\
\hline & \multirow[t]{3}{*}{$\mathrm{O}_{3}$} & Fry (2012) & HTAP, 11 models, 4 source regions & $\begin{array}{l}+0.05 \text { to }+0.08 \\
\text { depending on region }\end{array}$ \\
\hline & & Stevenson et al. (2013) & ACCMIP, 6 models & $+0.11(+0.08$ to 0.14$)$ \\
\hline & & This study & ECLIPSE, 3 models, 3 source regions & $\begin{array}{l}+0.03 \text { to }+0.06(+0.03 \text { to }+0.07) \\
\text { depending on region }\end{array}$ \\
\hline & \multirow[t]{2}{*}{ Aerosols } & Fry (2012) & HTAP, 11 models, 4 source regions, sulfate ari only & $\begin{array}{l}-0.005 \text { to }-0.01 \\
\text { depending on region }\end{array}$ \\
\hline & & This study & ECLIPSE, 3 models, 3 source regions, ari+aci & $\begin{array}{l}+0.02 \text { to }+0.05(-0.01 \text { to }+0.12) \\
\text { depending on region }\end{array}$ \\
\hline
\end{tabular}


Table 1. Continued.

\begin{tabular}{|c|c|c|c|c|}
\hline $\begin{array}{l}\text { Emitted } \\
\text { compound }\end{array}$ & $\begin{array}{l}\text { Climate } \\
\text { forcer }\end{array}$ & Reference & Method & $\begin{array}{l}\text { SRF } \\
\left(\mathrm{mW} \mathrm{m}^{-2}\left(\mathrm{Tg} \mathrm{yr}^{-1}\right)^{-1}\right)\end{array}$ \\
\hline \multirow[t]{8}{*}{ NMVOC } & \multirow[t]{3}{*}{$\mathrm{CH}_{4}$} & Fry (2012) & HTAP, 11 models, 4 source regions & $\begin{array}{l}+0.2 \text { to }+0.4 \\
\text { depending on region }\end{array}$ \\
\hline & & Stevenson et al. (2013) & ACCMIP, 6 models & $+0.27(+0.00$ to +0.41$)$ \\
\hline & & This study & ECLIPSE, 3 models, 3 source regions, includes primary-mode $\mathrm{O}_{3}$ & $\begin{array}{l}+0.35 \text { to }+0.66(+0.02 \text { to }+0.93) \\
\text { depending on region }\end{array}$ \\
\hline & \multirow[t]{3}{*}{$\mathrm{O}_{3}$} & Fry (2012) & HTAP, 11 models, 4 source regions & $\begin{array}{l}+0.2 \text { to }+0.4 \\
\text { depending on region }\end{array}$ \\
\hline & & Stevenson et al. (2013) & ACCMIP, 6 models & $+0.34(+0.21$ to +0.39$)$ \\
\hline & & This study & ECLIPSE, 3 models, 3 source regions & $\begin{array}{l}+0.63 \text { to }+1.15(+0.31 \text { to }+1.48) \\
\text { depending on region }\end{array}$ \\
\hline & \multirow[t]{2}{*}{ Aerosols } & Fry (2012) & HTAP, 11 models, 4 source regions, sulfate ari only & $\begin{array}{l}-0.1 \text { to } 0 \\
\text { depending on region }\end{array}$ \\
\hline & & This study & ECLIPSE, 3 models, 3 source regions, ari+aci & $\begin{array}{l}-0.18 \text { to }-0.74(-1.48 \text { to }+0.86) \\
\text { depending on region }\end{array}$ \\
\hline
\end{tabular}

BC concentrations and absorption aerosol optical depth. This upward scaling has been challenged by recent studies, which reduce the $\mathrm{BC}$ underestimation in their models by instead improving the model horizontal resolution (Wang et al., 2014a) or reducing BC lifetime (Samset et al., 2014). Taken together, the variable experimental designs of multi-model studies and different choices made to account for diversity hinder a clean assessment of the metrics uncertainty caused by diversity in RF estimates (Fuglestvedt et al., 2010).

In addition, several policy choices are not addressed by existing studies. First, they do not include all radiative forcing mechanisms consistently. RFaci and contributions to BC $\mathrm{RF}$ from deposition on snow and rapid adjustments from the semi-direct effect are often excluded. Then, although it is clearly important to take a regional view like that of Fry (2012) and Yu et al. (2013), it is potentially equally important to account for the seasonality of the emissions. RF mechanisms based on perturbations of sunlight are obviously strongly seasonal, so it is misleading to use year-long perturbations to quantify mitigation options that mostly act, because of the short lifetimes of NTCFs, for wintertime (e.g. domestic heating) or summertime (e.g. air conditioning) periods.

To remove those limitations, the Evaluating the $\mathrm{CLi}$ mate and Air Quality ImPacts of Short-livEd Pollutants (ECLIPSE) project (Stohl et al., 2015) built a matrix of SRFs that includes several NTCFs, varies the region and time of emissions, and spans diversity among models. This study documents that matrix while providing potential solutions for reducing model diversity. SRFs are calculated for reductions in the anthropogenic emissions of primary aerosols (BC, OC), aerosol precursors (sulfur dioxide, ammonia), ozone and secondary aerosol precursors $\left(\mathrm{NO}_{x}, \mathrm{CO}\right.$, VOC), and methane. The regional view comes from focusing on two source regions, Europe and East Asia, and singling out the shipping sector. Emissions are perturbed seasonally to assess which of local summer or wintertime emission reductions are most effective at exerting an SRF. Most radia- tive mechanisms are also quantified: RFaci is systematically included, ozone precursor RFs include a contribution from aerosol changes that arise through aerosol-chemistry couplings, and contributions to BC RF from deposition on snow and rapid adjustments from the semi-direct effect are also estimated, albeit from a single model. This study neglects the very weak ozone and methane RF exerted by perturbations of aerosol primary or precursor emissions through changes in $\mathrm{OH}$ distributions.

The paper is structured as follows. Section 2 describes the participating models and experimental design. Section 3 quantifies the components of SRF simulated by each model as a function of emitted species, region, and season. Causes of model diversity are also identified and discussed. Section 4 gives the best estimate of the SRF matrix resulting from the ECLIPSE project. Finally, Sect. 5 concludes with a discussion of research priorities for decreasing model diversity, recommendations for climate mitigation options, and possible solutions to the difficulties encountered when quantifying rapid adjustments. Supplement figures show annually averaged distributions of RF components for all perturbations.

\section{Models and experimental protocol}

Participating models are ECHAM6-HAM2, HadGEM3GLOMAP, NorESM1, and OsloCTM2. It is known from previous participations of those models in multi-model intercomparisons (Myhre et al., 2013b; Stevenson et al., 2013; Shindell et al., 2013) that those four models span a large range of inter-model diversity for both aerosol and ozone. Models differ in horizontal and vertical resolution and in the number of aerosol species included (Table 2). In particular, OsloCTM2 is the only model that represents nitrate aerosols. ECHAM6 does not simulate secondary organic aerosols and also lacks interactive ozone chemistry; thus it did not perform perturbations to ozone precursor emissions.

ECHAM6-HAM2 is the European Centre for MediumRange Weather Forecasts (ECMWF) Hamburg model ver- 
Table 2. List of models participating in the ECLIPSE radiative forcing simulations. Models are either general circulation models (GCM) or chemistry-transport models (CTM). Resolution indicates the horizontal resolution, in degrees, and the number of vertical levels. Crosses indicate which aerosol species are represented in each model, among sulfate $\left(\mathrm{SO}_{4}\right)$, black carbon $(\mathrm{BC})$, organic carbon $(\mathrm{OC})$, secondary organic aerosol (SOA), and nitrate $\left(\mathrm{NO}_{3}\right)$ aerosols. Chemistry indicates whether the model includes an interactive tropospheric ozone chemistry scheme. Radiation indicates whether radiation calculations are done interactively (online) or offline from monthly distributions. Note that ozone radiative forcing calculations are done offline for all models.

\begin{tabular}{llllllllll}
\hline Model & Type & Resolution & $\mathrm{SO}_{4}$ & $\mathrm{BC}$ & $\mathrm{OC}$ & $\mathrm{SOA}$ & $\mathrm{NO}_{3}$ & Chemistry & Radiation \\
\hline ECHAM6-HAM2 & $\mathrm{GCM}$ & $1.8^{\circ} \times 1.8^{\circ} \mathrm{L} 31$ & $\mathrm{X}$ & $\mathrm{X}$ & $\mathrm{X}$ & & & & Online \\
HadGEM3-GLOMAP & $\mathrm{GCM}$ & $1.8^{\circ} \times 1.2^{\circ} \mathrm{L} 38$ & $\mathrm{X}$ & $\mathrm{X}$ & $\mathrm{X}$ & $\mathrm{X}$ & & $\mathrm{X}$ & Online \\
NorESM1-M & $\mathrm{GCM}$ & $1.9^{\circ} \times 2.5^{\circ} \mathrm{L} 26$ & $\mathrm{X}$ & $\mathrm{X}$ & $\mathrm{X}$ & $\mathrm{X}$ & & $\mathrm{X}$ & Online \\
OsloCTM2 & $\mathrm{CTM}$ & $2.8^{\circ} \times 2.8^{\circ} \mathrm{L} 60$ & $\mathrm{X}$ & $\mathrm{X}$ & $\mathrm{X}$ & $\mathrm{X}$ & $\mathrm{X}$ & $\mathrm{X}$ & Offline \\
\hline
\end{tabular}

sion 6 (Stevens et al., 2013). Its radiation scheme is RRTM-G (Iacono et al., 2008). Aerosols are represented by the twomoment Hamburg Aerosol Model (HAM) version 2 (Zhang et al., 2012), which consists of the microphysical module M7 that simulates seven internally mixed aerosol modes (Vignati et al., 2004; Stier et al., 2005). Aerosol interactions with liquid and frozen water clouds follow Lohmann et al. (2007).

HadGEM3 is the Hadley Centre Global Environment Model version 3 (Hewitt et al., 2011). Its radiation scheme is described by Edwards and Slingo (1996). Gas-phase chemistry is modelled by the United Kingdom Chemistry and Aerosols (UKCA) TropIsop scheme, which treats 55 chemical species (37 of which being transported) including hydrocarbons and isoprene and its degradation products (O'Connor et al., 2014). Aerosols are coupled to the chemistry, and modelled by UKCA-GLOMAP (GLobal Model of Aerosol Processes; Mann et al., 2010), which represents the size-resolved internal mixture using a two-moment modal approach and four soluble and insoluble aerosol modes. Aerosols interact with liquid clouds only, following the empirical relationship between aerosol number and cloud droplet number concentration established by Jones et al. (1994).

NorESM1-M is the Norwegian Earth System Model version 1 (Bentsen et al., 2013; Iversen et al., 2013). Its atmosphere and aerosol module is CAM4-Oslo (Kirkevåg et al., 2013) and the radiation scheme is described by Collins (2001). In the version used in this study, aerosols (described by 20 tracers) are fully coupled to the MOZART tropospheric gas-phase chemistry scheme (Emmons et al., 2010), which treats 84 gaseous species. Aerosol mass concentrations are simulated in four size classes: nucleation, Aitken, accumulation, and coarse modes.

OsloCTM2 is the chemistry-transport model (CTM) of the University of Oslo and the Center for International Climate and Environmental Research - Oslo (CICERO; Myhre et al., 2009; Skeie et al., 2011). The model is driven by meteorological data generated by the Integrated Forecast System (IFS) model at ECMWF. The model simulates the tropospheric chemistry of 67 species (Dalsøren et al., 2007). Aerosols are simulated as external mixtures of seven aerosol types, including nitrate, as described by Skeie et al. (2011). RFari and RFaci are computed by offline radiative transfer calculations, as described in Myhre et al. (2007b) and Skeie et al. (2011). Myhre et al. (2000) describe the offline calculations performed to obtain ozone radiative forcing.

The 48 ECLIPSE RF simulations are listed in Table 3. Simulations are free-running with fixed sea-surface temperature and sea-ice distributions. Simulations last only 1 year after spin-up because RF by definition excludes changes in the tropospheric state so interannual differences in meteorology are the only source of variability between simulations. Meteorology affects transport and removal processes, especially wet deposition, and to a lesser extent chemical production when driven by temperature or availability of sunlight. Perturbation simulations made with HadGEM3 were extended to 3 years and suggest that interannual variability never exceeds $\pm 10 \%$ of globally averaged RF, which is small compared to inter-model diversity.

Control emissions are taken from the ECLIPSE dataset version 4a (Stohl et al., 2015; http://www.iiasa.ac.at/web/ home/research/researchPrograms/air/ECLIPSEv4a.html) for the year 2008. A seasonal cycle has been applied to the emissions of the domestic sector to reflect changes in domestic heating as a function of temperature. This seasonal cycle is obtained by multiplying annual total domestic sector emissions by a gridded dataset of monthly weights, obtained by the Mitigation of Arctic warming by Controlling European Black carbon emissions (MACEB) project following Sect. 3.3 of Streets et al. (2003), where stove operation times are expressed as a function of climatological monthly-mean temperature.

Emission perturbations involve a $20 \%$ decrease of primary and precursor emissions of the given species in one of the following regions: Europe, East Asia, shipping, and the rest of the world (RotW). Results for RotW are not presented directly in this paper; instead, global results are given by adding Europe, East Asia, and RotW together. Applying a decrease, rather than an increase, has been chosen because it better represents scientific recommendations to air quality and climate policy (Schmale et al., 2014). The value of $20 \%$ was chosen to be representative of typical techno- 
Table 3. List of simulations made to provide radiative forcing by regional and seasonal perturbations and size of the emission perturbation applied to the anthropogenic component for the year 2008, in $\mathrm{Tg} \mathrm{yr}^{-1}$. For some ozone precursors, HadGEM3 also perturbed the biomassburning component, so the size of its perturbation is given in parentheses $(\mathrm{H}:)$ for species and regions with strong biomass-burning sources. Emitted masses are in [C] for black and organic carbon and volatile organic compounds. They are in $\left[\mathrm{NO}_{2}\right]$ for $\mathrm{NO}_{x}$.

\begin{tabular}{|c|c|c|c|}
\hline \multirow[t]{2}{*}{ No. } & \multirow[t]{2}{*}{ Perturbation applied } & \multicolumn{2}{|c|}{$\begin{array}{l}\text { Emission perturbation } \\
\quad\left(\mathrm{Tg} \mathrm{yr}^{-1}\right)\end{array}$} \\
\hline & & May-Oct & Nov-Apr \\
\hline 1 & None (control simulation) & & \\
\hline 2 & $\mathrm{SO}_{2}$ emissions reduced by $20 \%$ in Europe & -0.77 & -0.85 \\
\hline 3 & $\mathrm{SO}_{2}$ emissions reduced by $20 \%$ in East Asia & -3.14 & -3.35 \\
\hline 4 & $\begin{array}{l}\mathrm{SO}_{2} \text { emissions reduced by } 20 \% \text { outside Europe, } \\
\text { East Asia, and shipping sector }\end{array}$ & -5.1 & -5.2 \\
\hline 5 & BC emissions reduced by $20 \%$ in Europe & -0.03 & -0.05 \\
\hline 6 & BC emissions reduced by $20 \%$ in East Asia & -0.11 & -0.18 \\
\hline 7 & $\begin{array}{l}\text { BC emissions reduced by } 20 \% \text { outside Europe, } \\
\text { East Asia, and shipping sector }\end{array}$ & -0.35 & -0.36 \\
\hline 8 & OC emissions reduced by $20 \%$ in Europe & -0.04 & -0.07 \\
\hline 9 & OC emissions reduced by $20 \%$ in East Asia & -0.21 & -0.37 \\
\hline 10 & $\begin{array}{l}\text { OC emissions reduced by } 20 \% \text { outside Europe, } \\
\text { East Asia, and shipping sector }\end{array}$ & -0.80 & -0.83 \\
\hline 11 & $\mathrm{NH}_{3}$ emissions reduced by $20 \%$ in Europe & -0.39 & -0.39 \\
\hline 12 & $\mathrm{NH}_{3}$ emissions reduced by $20 \%$ in East Asia & -1.37 & -1.35 \\
\hline 13 & $\begin{array}{l}\mathrm{NH}_{3} \text { emissions reduced by } 20 \% \text { outside Europe, } \\
\text { East Asia, and shipping sector }\end{array}$ & -3.48 & -3.43 \\
\hline 14 & $\mathrm{NO}_{x}$ emissions reduced by $20 \%$ in Europe & -1.00 & -1.06 \\
\hline 15 & $\mathrm{NO}_{x}$ emissions reduced by $20 \%$ in East Asia & -2.03 & -2.11 \\
\hline 16 & $\begin{array}{l}\mathrm{NO}_{x} \text { emissions reduced by } 20 \% \text { outside Europe, } \\
\text { East Asia, and shipping sector }\end{array}$ & $-6.27(\mathrm{H}:-7.17)$ & $-6.37(\mathrm{H}:-6.69)$ \\
\hline 17 & VOC emissions reduced by $20 \%$ in Europe & -0.06 to -0.28 & -0.07 to -0.36 \\
\hline 18 & VOC emissions reduced by $20 \%$ in East Asia & -0.15 to -0.55 & -0.19 to -0.84 \\
\hline 19 & $\begin{array}{l}\text { VOC emissions reduced by } 20 \% \text { outside Europe, } \\
\text { East Asia, and shipping sector }\end{array}$ & -0.15 to -4.08 & -0.19 to -4.17 \\
\hline 20 & CO emissions reduced by $20 \%$ in Europe & -2.43 & -3.09 \\
\hline 21 & CO emissions reduced by $20 \%$ in East Asia & $-12.82(\mathrm{H}:-12.91)$ & $-16.99(\mathrm{H}:-17.58)$ \\
\hline 22 & $\begin{array}{l}\text { CO emissions reduced by } 20 \% \text { outside Europe, } \\
\text { East Asia, and shipping sector }\end{array}$ & $-35.65(\mathrm{H}:-64.39)$ & $-35.10(\mathrm{H}:-51.40)$ \\
\hline 23 & All species of the shipping sector reduced by $20 \%$ & See $\mathrm{T}$ & ble 4. \\
\hline 24 & $\mathrm{CH}_{4}$ perturbations equivalent to global $20 \%$ emission reduction & See $\Delta E \mathrm{i}$ & Table 7. \\
\hline
\end{tabular}

logically feasible emission reductions. The same value was also used in previous HTAP simulations (Fry, 2012; Yu et al., 2013). The definition of regions follows tier-1 HTAP regions (Fig. 1). Here, Europe includes European Union and European Economic Area countries, as well as Switzerland, Turkey, and former Yugoslavia. East Asia includes China, Japan, Taiwan, North and South Korea, and Mongolia. Because of the specific impact of the shipping sector on air quality (Viana et al., 2014), its emissions have been perturbed independently, with all species emitted by that sector being perturbed together, although OsloCTM2 and NorESM1 have run perturbations for each species within the shipping sector (results not shown). Shipping emissions are taken from the RCP6.0 dataset (Fujino et al., 2006) prepared for phase 5 of the Climate Model Intercomparison project (CMIP5), inter- polated to 2008 between 2005 and 2010. All perturbations are applied either in Northern Hemisphere summer (MayOctober) or winter (November-April). The size of the emission perturbations is given in Table 3 and in Table 4 for shipping sector perturbations. The size of shipping emission perturbations is different for ECHAM6-HAM, because RCP8.5 (Riahi et al., 2007) was used, and for $\mathrm{NO}_{x}$ in NorESM1, because of a mistake when processing that particular dataset. The size of non-methane VOC emission perturbations is model dependent because the list of species emitted under the VOC label depends on the model used: 5 for HadGEM3, 14 for NorESM1, and 12 for OsloCTM2. As discussed in Sect. 3.3, differences in the VOC species included in the models add to SRF diversity. For OsloCTM2, VOC emis- 
Table 4. Size of the emission perturbation applied to the shipping sector for the year 2008, in $\mathrm{Tg}_{\mathrm{yr}}{ }^{-1}$. Emitted masses are in [C] for black and organic carbon, and volatile organic compounds. They are in $\left[\mathrm{NO}_{2}\right]$ for $\mathrm{NO}_{x}$. Emissions used in ECHAM6 and NorESM1 are denoted with $\mathrm{E}$ and $\mathrm{N}$, where different.

\begin{tabular}{lrr}
\hline \multirow{2}{*}{ Species } & \multicolumn{2}{c}{ Emission perturbation $\left(\mathrm{Tg} \mathrm{yr}^{-1}\right)$} \\
\cline { 2 - 3 } & May-Oct & Nov-Apr \\
\hline $\mathrm{SO}_{2}$ & $-1.04(\mathrm{E}:-1.25)$ & $-1.04(\mathrm{E}:-1.24)$ \\
$\mathrm{BC}$ & $-0.01(\mathrm{E}:-0.02)$ & $-0.01(\mathrm{E}:-0.02)$ \\
$\mathrm{OC}$ & $-0.01(\mathrm{E}:-0.02)$ & $-0.01(\mathrm{E}:-0.02)$ \\
$\mathrm{NO}_{x}$ & $-1.70(\mathrm{~N}:-1.10)$ & $-1.67(\mathrm{~N}:-1.10)$ \\
$\mathrm{VOC}$ & -0.04 to -0.21 & -0.04 to -0.21 \\
$\mathrm{CO}$ & -0.11 & -0.11 \\
\hline
\end{tabular}

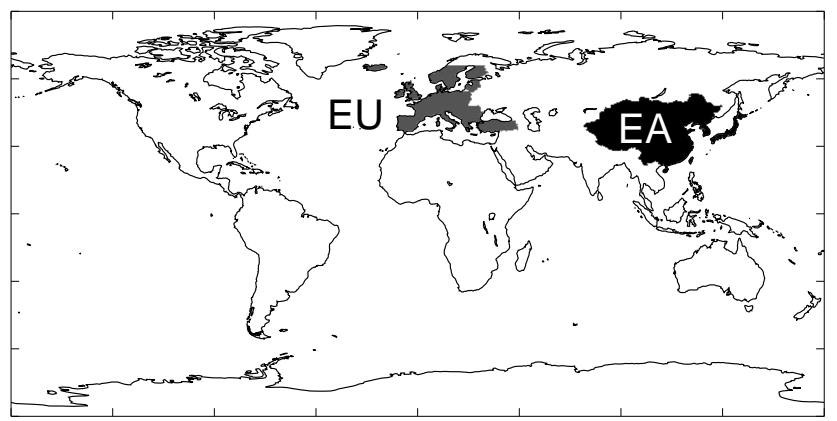

Figure 1. HTAP tier-1 regions used in the ECLIPSE specific radiative forcing matrix. EU stands for Europe and EA for East Asia.

sions were converted to unit mass of carbon by assuming a mean VOC atomic weight of $47 u$.

Methane perturbations are achieved by scaling the prescribed concentrations or mass-mixing ratios rather than by perturbing emissions like for the other NTCFs. This difference in treatment arises because HadGEM3, NorESM1, and OsloCTM2 prescribe global-mean methane concentrations at the surface and then let the chemistry scheme determine the vertical distribution, thus avoiding long spin-ups caused by the 12-year lifetime of methane in the atmosphere. Scaled methane surface concentrations $C$ are given by the equation:

$C=C_{0} \cdot\left(E / E_{0}\right)^{f}$,

where $C_{0}$ is the control surface concentration, $E$ is the global emission rate where the anthropogenic contribution has been reduced by $20 \%$, and $E_{0}$ is the control global emission rate. $E / E_{0}$ is therefore equal to 0.8 in this study. $f$ is the feedback factor of methane on its own lifetime, defined as the ratio of methane perturbation lifetime to total budget lifetime. The value of $f$ for each participating model was not known when preparing the simulations and was therefore taken at 1.34 following Holmes et al. (2013). As discussed in Sect. 3.2, actual values of $f$ range from 1.28 to 1.46 , in reasonable agreement with the value initially assumed. Because the long atmo-
Table 5. Simulated lifetime, in days, of aerosol species and tropospheric ozone in the four participating models.

\begin{tabular}{lcccc}
\hline Species & ECHAM6 & HadGEM3 & NorESM1 & OsloCTM2 \\
\hline Sulfate & 4.0 & 5.2 & 4.2 & 3.5 \\
BC & 5.2 & 5.7 & 8.0 & 6.2 \\
OC & 5.0 & 6.6 & 7.7 & 5.0 \\
Tropospheric & n/a & 20.7 & 26.4 & $\begin{array}{c}\text { Not } \\
\text { ozone }\end{array}$ \\
\hline
\end{tabular}

spheric lifetime of methane allows it to be well mixed geographically, methane perturbations are not applied regionally. NorESM1 applied perturbations seasonally (May-October and November-April) and found differences in SRF of only $7 \%$ between the two seasons. Because that seasonal dependence is small, OsloCTM2 and HadGEM3 have applied the perturbation for the whole year.

RF is calculated at the top of the atmosphere as the difference in net short-wave and long-wave radiative fluxes between the perturbed and control simulations. More specifically, three methods are used to obtain stratospherically adjusted RF from the perturbation simulations, depending on the species being considered and whether the model is capable of interactive radiation calculations (Table 1).

- To obtain the RF of aerosol perturbations in general circulation models, the model evolution (its "meteorology") is set to be independent of the perturbation. The method used to achieve this independence involves diagnosing radiative fluxes with and without the perturbation to the forcing agent included, with the second set of radiative fluxes used to advance the model into its next time step. Stratospheric adjustment is neglected for aerosols because tropospheric aerosol perturbations have little effect on stratospheric temperatures. Aerosol RF includes both ari and aci, except for ECHAM6, which only diagnosed ari.

- To obtain the RF of aerosol perturbations in chemistrytransport models and the RF of ozone exerted by ozoneprecursor perturbations in all models, instantaneous RF is computed by offline radiative transfer codes, using aerosol and trace gas distributions obtained from the perturbation simulations. HadGEM3 ozone RF is computed with the offline version of the radiative transfer code by Edwards and Slingo (1996). OsloCTM2 aerosol and ozone RF and NorESM1 ozone RF are computed with offline long-wave and short-wave radiative transfer codes as described in Myhre et al. (2000, 2007b) and Skeie et al. (2011). For all models, ozone RF is adjusted for changes in stratospheric temperatures.

- The RF of methane is computed using the analytical expression established by Myhre et al. (1998), which accounts for stratospheric adjustments. Details of this calculation are given in Sect. 3.2 below. 
The four models simulate different aerosol and tropospheric ozone lifetimes, as shown in Table 5. Sulfate and BC aerosol lifetimes vary by a factor 1.5. Modelled OC lifetime has a larger diversity, with variations by a factor 2.5 . Tropospheric ozone lifetime is also diverse: HadGEM3 and NorESM1 disagree by a factor 1.3. OsloCTM2 did not diagnose it. Differences in simulated lifetimes are thought to arise from virtually all aspects of the models, including differences in the simulated present-day climate, the treatment of atmospheric horizontal and vertical transport, atmospheric chemistry, and wet and dry deposition processes. Large model spreads have long been a characteristics of aerosol and chemistry intercomparisons (e.g. Myhre et al., 2013b; Stevenson et al., 2013), in part because of a lack of strong observational constraints on atmospheric lifetimes on a global scale (Kristiansen et al., 2012; Hodnebrog et al., 2014). The four ECLIPSE models are representative of those spreads.

Aerosol and ozone distributions simulated by the four models participating in this study have been compared to observations as part of their development cycles (Bellouin et al., 2011; Kirkevåg et al., 2013; O'Connor et al., 2014; Skeie et al., 2011; Zhang et al., 2012), multi-model intercomparisons (Koffi et al., 2016; Pan et al., 2015; Stevenson et al., 2013; Tsigaridis et al., 2014), and within the ECLIPSE project (Eckhardt et al., 2015; Quennehen et al., 2016; Schulz et al., 2015). Those evaluations draw a complex picture, where model skill at reproducing NTCF distributions with fidelity differs among models and strongly depends on region and species. Quennehen et al. (2016) compared the four ECLIPSE models to MODIS (Moderate Resolution Imaging Spectroradiometer) aerosol optical depth (AOD) retrievals and Cloud-Aerosol Lidar with Orthogonal Polarization (CALIOP) scattering profiles, finding qualitative agreement but quantitative discrepancies that depend on model, season, and region. The models tend to put aerosol scattering too high in the atmosphere, hinting that transport into the free troposphere is too efficient or sinks are too weak. Such errors in simulated vertical profiles may lead to too weak an SRFaci because aerosols end up being simulated above clouds instead of interacting with them. For BC, placing the aerosols too high in the atmosphere leads to overestimating RFari (Samset et al., 2013) and underestimating rapid adjustments from semi-direct effects, so the net impact on SRF depends on the local balance between those two mechanisms.

Evaluations of surface and total-column ozone (Schulz et al., 2015; Quennehen et al., 2016; O'Connor et al., 2014) find that OsloCTM2 does the best simulation, both in terms of magnitude and seasonality. HadGEM3 and NorESM1 tend to overestimate both surface concentrations and the ozone column. The three models locate ozone too low in the troposphere but are still able to qualitatively reproduce the gradients existing between surface concentrations in urban and rural conditions. However, modelled gradients are smoothed out because of the relatively coarse resolutions of the models.
RF and SRF cannot be evaluated against observations, so the challenge is to interpret what regional evaluations of surface concentrations, vertical profiles, and optical properties imply for globally averaged SRF to regional perturbations. Propagation of errors in the emission-concentration$\mathrm{RF}$ chain is often non-linear. Methane RF is proportional to the square root of its concentration (Myhre et al., 1998). Ozone RF efficiency increases with altitude in the troposphere with a maximum near the tropopause (Lacis et al., 1990) so ozone being located too low in models introduces a low bias in the SRF exerted by ozone precursors. Aerosol RF efficiency is affected by model failure to transport a NTCF to a region where surfaces are highly reflective (deserts, ice, and snow) or the cloud regime is strongly susceptible to aerosol influences (low maritime clouds). Locating BC aerosols too high up in the atmosphere so they end up overlying bright clouds can overestimate their RFari efficiency by up to a factor of 2 (Hodnebrog et al., 2014). Aerosol-cloud interactions inherit the strong non-linearities between aerosol and CCN concentrations (Hegg, 1994) and cloud droplet concentrations and cloud albedo (Taylor and McHaffie, 1994) so biases in concentrations will have strong impacts on RF estimates in regions where aerosol concentrations are small to moderate, away from sources. The normalised nature of SRF and non-linearities in the emission-to-forcing chain therefore preclude a simple scaling of modelled SRF with identified biases. This study therefore reports SRF as simulated by the models but highlights in the next section the implications of comparisons to observations for the SRF exerted by each species.

\section{Specific radiative forcing by species}

In this section, SRFs of aerosol, methane, ozone precursor, and shipping sector emission perturbations are discussed in turn. SRF is stratospherically adjusted but excludes rapid adjustments in the troposphere, with one exception: rapid adjustments of BC semi-direct effects have been computed independently and are discussed in Sect. 3.1. SRF is given for May-October (hereafter labelled summer for the sake of simplicity but also because emission perturbations are disproportionally located in the Northern Hemisphere) and NovemberApril (labelled winter), for three regions (Europe, East Asia, and global), and for the shipping sector. Globally averaged RF is computed as the sum of the European, East Asian, and RotW perturbations. Although perturbations are not exactly additive, this is a good first-order assumption.

\subsection{Aerosols and their precursors}

Figure 2 shows globally and annually averaged $\mathrm{SRF}$ for $\mathrm{SO}_{2}$, $\mathrm{BC}, \mathrm{OC}$, and ammonia $\left(\mathrm{NH}_{3}\right)$ perturbations in the ECLIPSE models. Ammonia perturbations have only been simulated by OsloCTM 2 because it is the only participating model that 

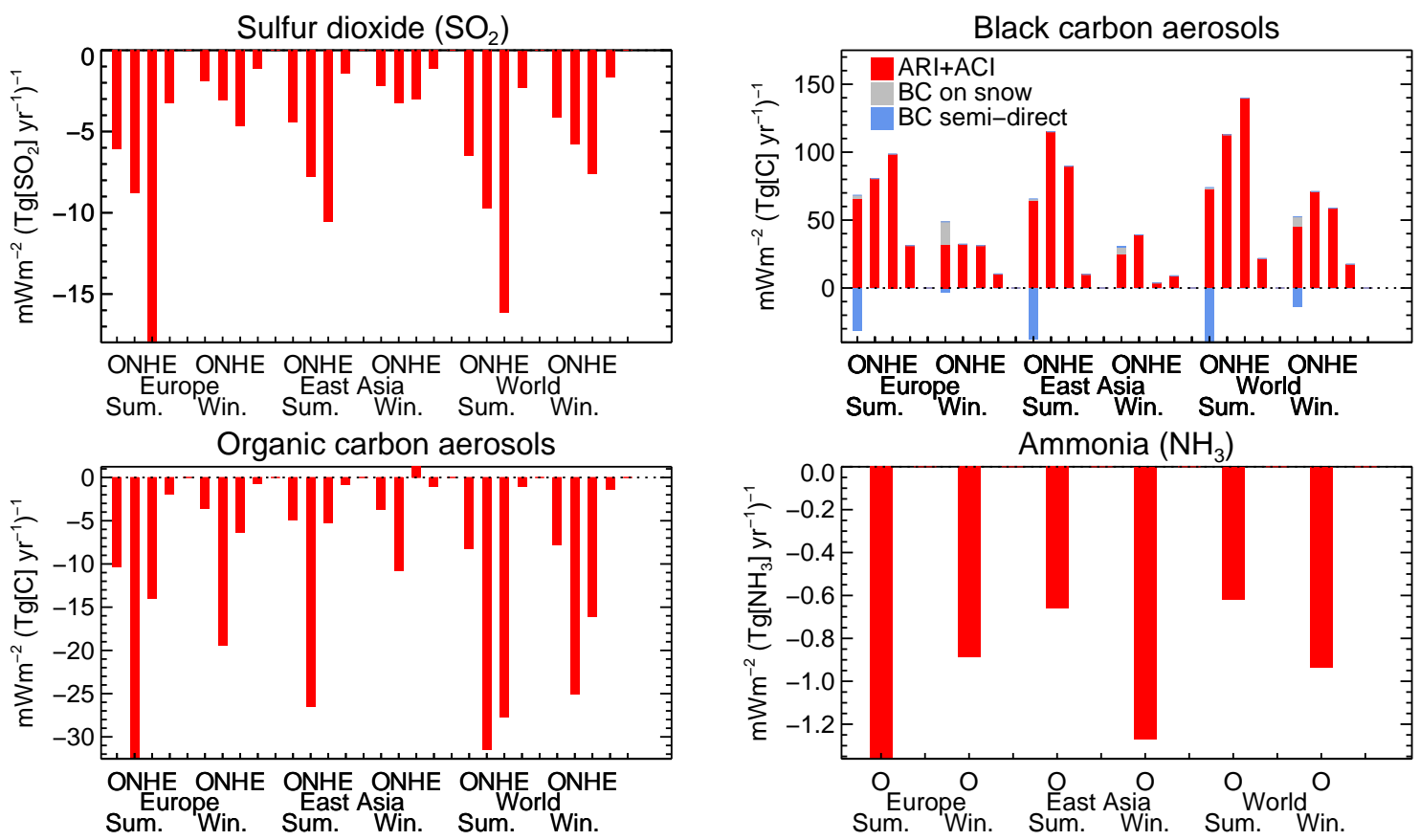

Figure 2. Specific radiative forcing, in $\mathrm{mW} \mathrm{m}^{-2}\left(\mathrm{Tg} \mathrm{yr}^{-1}\right)^{-1}$, for regional and seasonal reductions in sulfur dioxide, black carbon, organic carbon, and ammonia emissions. Results are obtained by four global models: OsloCTM2 (O), NorESM1 (N), HadGEM3 (H), and ECHAM6 (E) except for ammonia perturbations where only OsloCTM2 contributes. Three categories of radiative forcing mechanisms are included: aerosol-radiation and aerosol-cloud interactions (red, except for ECHAM6 where aerosol-cloud radiative forcing is not diagnosed), BC deposition on snow (grey, OsloCTM2 only), and rapid adjustments from the semi-direct effect of BC (blue, OsloCTM2 only).

represents the equilibrium between nitric acid, in the gas phase, and nitrate aerosols. ECHAM6 is consistently associated with weaker SRF than other models because it only diagnoses ari, therefore neglecting the often larger aci contribution; only for $\mathrm{BC}$ is aci a relatively minor component of aerosol RF - at 2 to $15 \%$ according to NorESM1 and OsloCTM2.

The SRFs exerted by $\mathrm{SO}_{2}, \mathrm{OC}$, and $\mathrm{NH}_{3}$ perturbations are negative. BC SRF is positive overall because the positive contributions from ari and snow-albedo mechanisms are only partly offset by negative contributions from aci and rapid adjustments from the semi-direct effect. All models agree that aerosol SRF is stronger for summer than winter perturbations, which is expected because RFari and RFaci act almost exclusively in the short-wave spectrum and are therefore a strong function of solar irradiance. As shown in Figs. S1 and S4 in the Supplement, sulfate and OC RF cover a larger area in models with longer sulfate and OC aerosol lifetimes (Table 5), such as HadGEM3, than in models with shorter lifetimes, like OsloCTM2. This extended coverage has two competing effects on the strength of SRF, both driven by nonlinearities in RFaci. On the one hand, a longer lifetime promotes stronger RFaci because emission perturbations propagate more easily to remote regions where concentrations are low and RFaci desaturates more easily. On the other hand, a longer lifetime weakens RFaci by increasing concentrations in the reference simulation in those same remote regions, saturating RFaci. The first effect appears to dominate in the ECLIPSE models because SRF strength increases with lifetime. RFaci non-linearities also explain why models simulate weaker SRFs for East Asian than European perturbations. With a more polluted baseline, East Asian aci stands more often at the saturated end of the $\mathrm{CCN}$-cloud albedo relationship, where RFaci is weak (Wilcox et al., 2015). Diversity in RFaci is further increased by variations in the strength of aci (Quaas et al., 2009) and different low cloud climatologies (Jiang et al., 2012).

Nitrate aerosol SRFs, whose distributions are shown in Fig. S5, have similar optical and cloud nucleus properties as sulfate aerosols, yet their SRFs are about 10 times weaker. This weakness is due to two factors. First, formation of ammonium nitrate competes against that of ammonium sulfate, which is favoured by its better thermodynamical stability (Metzger et al., 2002). The efficiency of nitrate precursor reductions therefore depends on regional sulfur dioxide levels. Conversely, the inclusion of nitrate aerosols in OsloCTM2 explains the relatively weak $\mathrm{SO}_{2} \mathrm{SRFs}$ is simulates, because a reduction in $\mathrm{SO}_{2}$ emissions indirectly favours nitrate formation (Bellouin et al., 2011). In that model, nitrate RFari offsets 4 to $10 \%$ of sulfate RFari, with larger offsets obtained in Northern Hemisphere winter months. Second, nitrate aerosols are semi-volatile and dissociate back into the 
gas phase when temperatures increase. Nitrate aerosol formation is therefore hindered during daytime (Dall'Osto et al., 2009), decreasing the ability of nitrate aerosols to interact with radiation. Sulfate aerosols have a more stable diurnal cycle, maximising their radiative forcing efficiency (RFE). Although only one ECLIPSE model represents nitrate aerosols, previous studies allow an assessment of likely model diversity in nitrate SRF. AeroCom models with nitrate representations produced estimates of nitrate RF efficiency that range from 60 to $160 \%$ of the eight-model median of $-155 \mathrm{~W} \mathrm{~g}\left[\mathrm{NO}_{3}\right]^{-1}$ (Myhre et al., 2013b). Modelled nitrate lifetimes reported for present-day conditions indicate sizeable diversity, with Bellouin et al. (2011) obtaining 3.1 days and Hauglustaine et al. (2014) having 4.6 days (50\% longer). Diversity of aerosol-cloud interactions for nitrate is assumed to be similar to the $10 \%$ obtained in this study for sulfate aerosols. Thus, a conservative estimate of nitrate SRF diversity is a factor of 2 each side of the OsloCTM2 estimate.

$\mathrm{BC}$ differs from sulfate and OC perturbations in showing no correlation between modelled lifetime and SRF. This lack of correlation has three main causes. First, BC aerosols exert, for a given optical depth and single-scattering albedo, a stronger RFari when located above bright than dark surfaces. Figure S2 shows that the long lifetime of BC in NorESM1 (which may be too long according to Eckhardt et al., 2015) translates into a strong RF over the Arctic for East Asian and global perturbations. Secondly, BC mass-absorption coefficients (MAC) vary among models because of different assumptions about refractive indices, mixing state, and hygroscopic growth. Globally averaged BC MAC for ambient conditions are $10.4 \mathrm{~m}^{2} \mathrm{~g}^{-1}$ in ECHAM6, $15.7 \mathrm{~m}^{2} \mathrm{~g}^{-1}$ in HadGEM3, only $3.8 \mathrm{~m}^{2} \mathrm{~g}^{-1}$ in NorESM1, and varies between $7.3 \mathrm{~m}^{2} \mathrm{~g}^{-1}$ for hydrophobic and $11.0 \mathrm{~m}^{2} \mathrm{~g}^{-1}$ for hydrophilic BC in OsloCTM2. Thirdly, HadGEM3 simulates negative BC SRFs over northern Russia for the global summer perturbation (Fig. S2) because of complex aerosol mixture effects where perturbations of primary BC emissions also perturb condensation of organic materials. In that model, having fewer primary particles suppresses the gaseous condensation sink and favours the nucleation of new CCNs in pristine regions (Bellouin et al., 2013).

The RF due to $\mathrm{BC}$ deposition on snow, shown in grey in Fig. 2, is only quantified by OsloCTM2. It is a small term globally and only important for winter perturbations when snow cover is maximum in the Northern Hemisphere, where fossil-fuel BC sources are mostly located. BC-on-snow RFs represent 15, 20, and $53 \%$ of winter RFari for global, East Asian, and European perturbations, respectively. The disproportionately strong contribution of the European perturbation is due to its geographical location: in spite of smaller BC emitted mass in Europe, Arctic RF is similar to that of East Asian emission perturbations (Fig. S3). So BC-on-snow SRF exerted by the European winter perturbation is more than 3 times stronger than for the East Asian winter perturbation and 2 times stronger than for the global winter perturbation.
Table 6. Semi-direct radiative forcing (SDRF) by regional and seasonal perturbations of black carbon aerosols. Column 3 gives the scaling factor imposed to let rapid adjustments from the semi-direct effect emerge from natural variability. Column 4 gives the corresponding specific SDRF, in $\mathrm{mW} \mathrm{m}^{-2}\left(\mathrm{Tg}[\mathrm{C}] \mathrm{yr}^{-1}\right)^{-1}$, and its standard deviation over the 30 years.

\begin{tabular}{llrr}
\hline Region & Season & $\begin{array}{r}\text { Scaling } \\
\text { factor }\end{array}$ & $\begin{array}{r}\text { Specific } \\
\text { SDRF }\end{array}$ \\
\hline Europe & Summer & 500 & $-31 \pm 13$ \\
& Winter & 500 & $-3 \pm 8$ \\
East Asia & Summer & 150 & $-38 \pm 12$ \\
& Winter & 150 & $+1 \pm 7$ \\
Global & Summer & 30 & $-40 \pm 18$ \\
& Winter & 30 & $-14 \pm 11$ \\
\hline
\end{tabular}

Jiao et al. (2014) assessed an offline land surface model with $\mathrm{BC}$ deposition rates simulated by AeroCom models, including OsloCTM2, finding that it strongly overestimates BCin-snow amounts compared to measurements in the Arctic, suggesting a possible overestimation of BC-on-snow SRF in this study.

Changes in aerosols may exert rapid adjustments that follow the perturbation to cloud droplet size distributions. Those are not quantified here because ECLIPSE models do not yet adequately represent the observed dependence of the strength and sign of rapid adjustments on cloud regime (Christensen and Stephens, 2011). In general, confidence in the ability of global models to represent those mechanisms with fidelity is low (Stevens and Feingold, 2009). In addition, rapid adjustments are difficult to isolate robustly from internal variability in cloud fraction and top-of-atmosphere radiative fluxes, especially for the small perturbations imposed in this study. However, BC aerosols are unusual among NTCFs because their strong absorption of short-wave radiation is expected to trigger strong rapid adjustments (Koch and Del Genio, 2010), which have been observed in marine stratocumulus regimes (Brioude et al., 2009; Wilcox, 2010). To quantify those adjustments, control and perturbed distributions of BC mass-mixing ratios simulated by OsloCTM2 are prescribed in 30-year, fixed sea-surface temperatures simulations with the Community Earth System Model (CESM) version 1.0.4 (Neale et al., 2010). RFari was quantified using multiple calls to the radiation scheme, following Ghan (2013). Because aci are not included in the CAM4 atmospheric component of the CESM, the rapid adjustments from the semi-direct effects of BC are calculated by subtracting its RFari from total ERF. The reference CESM simulation uses BC concentrations taken directly from the reference OsloCTM2 simulation. The changes in $\mathrm{BC}$ are therefore scaled before being prescribed in CESM to improve the signal-to-noise ratio between ERF and unforced variability in perturbation simulations. The scaling follows the equation 
$\mathrm{BC}_{\mathrm{CESM}}=\left(\mathrm{BC}_{\mathrm{REF}}-\mathrm{BC}_{\mathrm{PERT}}\right) \times S+\mathrm{BC}_{\mathrm{REF}}$,

where $\mathrm{BC}_{\mathrm{CESM}}$ are the distributions of $\mathrm{BC}$ concentrations prescribed into $\mathrm{CESM}$, and $\mathrm{BC}_{\mathrm{REF}}$ and $\mathrm{BC}_{\mathrm{PERT}}$ are OsloCTM2's reference and perturbed distributions, respectively. $S$ is the scaling factor and is larger for smaller perturbations (Table 6). Thus, European perturbations are scaled by a factor 500 but RotW perturbations only require a scaling factor of 30 . The application of such large scaling factors requires that rapid adjustments from the semi-direct effect scale linearly with the $\mathrm{BC}$ perturbation imposed. This has been checked by imposing increasing scaling factors of 15 , 50, 150, and 1500 to the East Asian summer perturbation. Corresponding semi-direct SRFs are $-44 \pm 121,-38 \pm 40$, $-38 \pm 12$, and $\left.-35 \pm 1 \mathrm{~mW} \mathrm{~m}^{-2}\left(\mathrm{Tg}_{\mathrm{C}} \mathrm{C}\right] \mathrm{yr}^{-1}\right)^{-1}$, indicating a satisfactory level of linearity and supporting the application of large scaling factors. Table 6 gives the statistics of the resulting semi-direct SRFs taken over the 30-year CESM simulations. With the exception of the East Asian winter perturbation, semi-direct SRF is negative, thus opposing the positive BC RFari. Semi-direct SRFs are weaker in winter than in summer perturbations, as expected from a mechanism driven by absorption of short-wave radiation. There are no strong regional variations in semi-direct SRFs. In spite of the large scaling factors imposed, statistics are fragile and $90 \%$ confidence intervals include $0 \mathrm{~mW} \mathrm{~m}^{-2}$ for winter perturbations. It is therefore important to keep in mind that the semi-direct component of BC SRF is even more uncertain than the other components, and may not be significantly different from zero.

As discussed in Sect. 2, identification of concentration biases hints at possible systematic errors in SRFs but requires accounting for non-linear dependencies of radiative efficiency with concentrations. ECLIPSE models underestimate sulfate aerosol surface concentrations in Europe because of underestimated $\mathrm{SO}_{2}$ oxidation rates (Schulz et al., 2015) and in the Arctic because of emissions and transport (Eckhardt et al., 2015). The lack of summer minimum in the Arctic may yield too weak an SRF in that region. For BC, ECLIPSE models generally underestimate $\mathrm{BC}$ aerosol surface concentrations in Europe (Schulz et al., 2015) and the Arctic (Eckhardt et al., 2015), possibly because of underestimated emissions. Gadhavi et al. (2015) similarly find that BC emission rates used in ECLIPSE are likely underestimated in India. Absorbing AOD retrievals from AERONET may also indirectly constrain $\mathrm{BC}$ concentrations in regions where mineral dust aerosols are not present and where $\mathrm{OC}$ aerosols do not strongly contribute to absorption, which may exclude biomass-burning regions (Saleh et al., 2014). However, limitations in the AERONET inversion algorithm (Dubovik et al., 2000) introduce systematic biases towards morning/evening conditions and for thicker plumes. Wang et al. (2015) also showed that the fairly low resolutions of global models like those used in this study induce an artificial negative bias

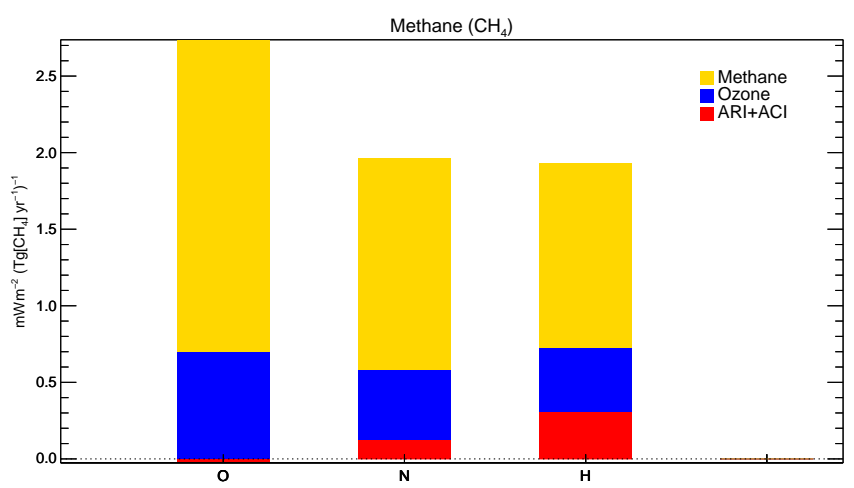

Figure 3. Specific radiative forcing, in $\mathrm{mW} \mathrm{m}^{-2}$ $\left(\mathrm{Tg}\left[\mathrm{CH}_{4}\right] \mathrm{yr}^{-1}\right)^{-1}$, for global and annual reductions in equivalent methane emissions (see Sect. 3.2 for details). Results are obtained by three global models: OsloCTM2 (O), NorESM1 (N), and HadGEM3 (H). Three categories of radiative forcing mechanisms are included: aerosol-radiation and aerosol-cloud interactions (red), short-term changes in ozone (blue), and methane (yellow).

when comparing to AERONET stations in Asia. So the fact that ECLIPSE models underestimate AERONET-retrieved absorbing AOD by more than a factor 2 (Schulz et al., 2015), which could be evidence for underestimated BC concentrations, may be predominantly caused by sampling differences between models and AERONET. In contrast, models overestimate $\mathrm{BC}$ radiative efficiency by systematically overestimating BC concentrations at higher altitudes in the remote troposphere (Samset et al., 2014). According to Hodnebrog et al. (2014), the balance between underestimated emissions and overestimated efficiencies translates into BC SRF being too strong by up to a factor 2 . For OC, surface concentrations are generally underestimated in Europe (Schulz et al., 2015) and at urban, remote, and marine sites worldwide (Tsigaridis et al., 2014) because of underestimated primary emissions and secondary aerosol formation. Those underestimations may bias OC SRF high, especially for the aci component.

\subsection{Methane}

As discussed in Sect. 2, methane perturbations have been applied globally and annually instead of regionally and seasonally. This simplification is motivated by technical considerations, because the long lifetime of methane would necessitate long model spin-ups, and justified by the relatively well mixed nature of methane in the atmosphere compared to shorter-lived species. The regional and seasonal nature of perturbations is therefore quickly lost, all perturbations converging into similar SRFs.

The SRF exerted by methane itself is computed analytically on a global average in a four-stage calculation:

- First, the methane feedback factor $f$ is derived from each model using Eqs. (2) and (3) of Stevenson et 
Table 7. Characteristics of the methane budget in ECLIPSE models. For NorESM1, numbers are given for the summer perturbation simulation. From left to right, columns give methane lifetime to destruction by $\mathrm{OH}\left(\tau_{\mathrm{OH}}\right)$, in years, for the control $(\mathrm{Ctl})$ and perturbed $(\mathrm{Per})$ simulations; total methane lifetime $\left(\tau_{\text {tot }}\right)$, in years, in Ctl and Per simulations; total methane burden $(B)$, in $\mathrm{Tg}\left[\mathrm{CH}_{4}\right]$, in $\mathrm{Ctl}$ and Per simulations; methane feedback factor $(f)$; equivalent methane emission perturbation $(\Delta E)$, in $\mathrm{Tg}_{[}\left[\mathrm{CH}_{4}\right] \mathrm{yr}^{-1}$; methane radiative forcing (RF), in

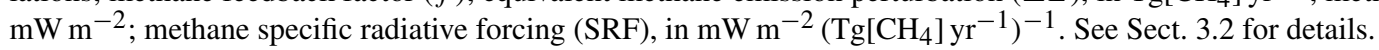

\begin{tabular}{|c|c|c|c|c|c|c|c|c|c|c|}
\hline \multirow[t]{2}{*}{ Model } & \multicolumn{2}{|c|}{$\tau_{\mathrm{OH}}$} & \multicolumn{2}{|c|}{$\tau_{\text {tot }}$} & \multicolumn{2}{|c|}{$B$} & \multirow[t]{2}{*}{$f$} & \multirow[t]{2}{*}{$\Delta E$} & \multirow[t]{2}{*}{$\mathrm{RF}$} & \multirow[t]{2}{*}{ SRF } \\
\hline & $\mathrm{Ctl}$ & Per & $\mathrm{Ctl}$ & Per & $\mathrm{Ctl}$ & Per & & & & \\
\hline HadGEM3 & 6.0 & 5.6 & 5.5 & 5.2 & 4561 & 3702 & 1.34 & 117 & 123 & 1.21 \\
\hline NorESM1 & 7.8 & 7.7 & 7.0 & 6.9 & 4815 & 4489 & 1.28 & 36.5 & 44 & 1.38 \\
\hline OsloCTM2 & 10.2 & 9.6 & 8.9 & 8.4 & 4909 & 4115 & 1.46 & 61 & 109 & 2.04 \\
\hline
\end{tabular}

al. (2013), which requires the knowledge of control and perturbed methane burdens, and total methane lifetime $\tau_{\text {tot }} \cdot \tau_{\text {tot }}$ accounts for three methane sinks: destruction by $\mathrm{OH}$, which is diagnosed in each model, and losses to the stratosphere and soils, with lifetimes of 120 and 160 years, respectively (Stevenson et al., 2013). ECLIPSE feedback factors range from 1.28 to 1.46 (Table 7), in close agreement with the multi-model mean derived by Holmes et al. (2013).

- In a second step, the equivalent methane emission perturbation $\Delta E$ is computed as

$$
\Delta E=\Delta B /\left(f \times \tau_{\mathrm{tot}}\right),
$$

where $\Delta B$ is the change in burden between the control and perturbed simulations.

- The third step computes methane RF in each model by inserting control and perturbed methane volume mass-mixing ratios in the formula established by Myhre et al. (1998). The mass-mixing ratio of nitrous oxide $\left(\mathrm{N}_{2} \mathrm{O}\right)$ used in that calculation is $325 \mathrm{ppb}$ (WMO, 2014).

- Finally, methane SRF is computed as the RF divided by $\Delta E$ and increased by $15 \%$ to represent the increase in stratospheric water vapour that follows methane oxidation (Myhre et al., 2007b).

Methane burdens, lifetimes, and all the global averages involved in computing the methane contribution to total methane SRF in the three ECLIPSE models are given in Table 7. Simulated methane lifetimes vary by a factor 1.6 , reproducing the diversity seen in past studies (Voulgarikis et al., 2013). It is important to note that the diversity in modelled methane SRF is not due to uncertainties in the radiative properties of the molecule but rather due to the diversity in simulating present-day burdens, which affects the baseline of a non-linear RF.

In addition to the SRF exerted by methane itself, components due to perturbations to aerosols and ozone precursors contribute to total methane SRF (Fig. 3). Aerosol and ozone RFs are derived using the methods described in Sect. 2. The aerosol component arises from the increase in $\mathrm{OH}$ that follows the decrease in $\mathrm{CH}_{4}$ concentrations, promoting $\mathrm{SO}_{2}$ oxidation into sulfate aerosols that contribute a negative RF. That contribution is very diverse among models, varying from weakly negative in OsloCTM2 to strongly positive in HadGEM3. The OsloCTM2 value is from a simplified calculation, which only represents ari by using distributions of RFEs instead of the full radiative transfer calculations normally used. Three other aspects of the models increase the diversity in estimates of aerosol contributions to methane SRF. Firstly, the size of the relative increase in global $\mathrm{OH}$ burden that follows the decrease in methane concentrations is larger in HadGEM3, at $+7 \%$, than in NorESM1 and OsloCTM2, at +4.5 and $+4.6 \%$, respectively. Secondly, other limitations restrict the aerosol response in some models, but not others. For example, NorESM simulates aerosol SRFs of differing signs (Fig. S6), which indicate different responses of local chemistry, possibly mediated by changes in oxidation pathways by $\mathrm{O}_{3}$ and $\mathrm{H}_{2} \mathrm{O}_{2}$. In HadGEM3, however, aerosol SRF is uniformly positive across the globe (Fig. S6), indicating that once $\mathrm{OH}$ is increased, no further limitation restricts the size of the aerosol response. The realism of those responses is difficult to confirm from observations, as evidence for changes in the oxidising capacity of the atmosphere are lacking. Thirdly, the inclusion of nitrate aerosols in OsloCTM2 counteracts the sulfate aerosol response because increases in ammonium sulfate aerosol formation are detrimental to ammonium nitrate aerosol formation.

In contrast to the diversity seen in the aerosol component of total methane SRF, all three models simulate ozone contributions to methane SRF close to one third of the SRF of methane itself. This chemical feedback is therefore in good agreement among models and is proportional to the size of the methane perturbation. Figure S7 shows that the models also agree well on the geographical distribution of the ozone SRF, with a maximum at the tropical boundaries.

\subsection{Ozone precursors}

Figure 4 shows globally and annually averaged SRF for nitrogen oxide, volatile organic compounds, and carbon 

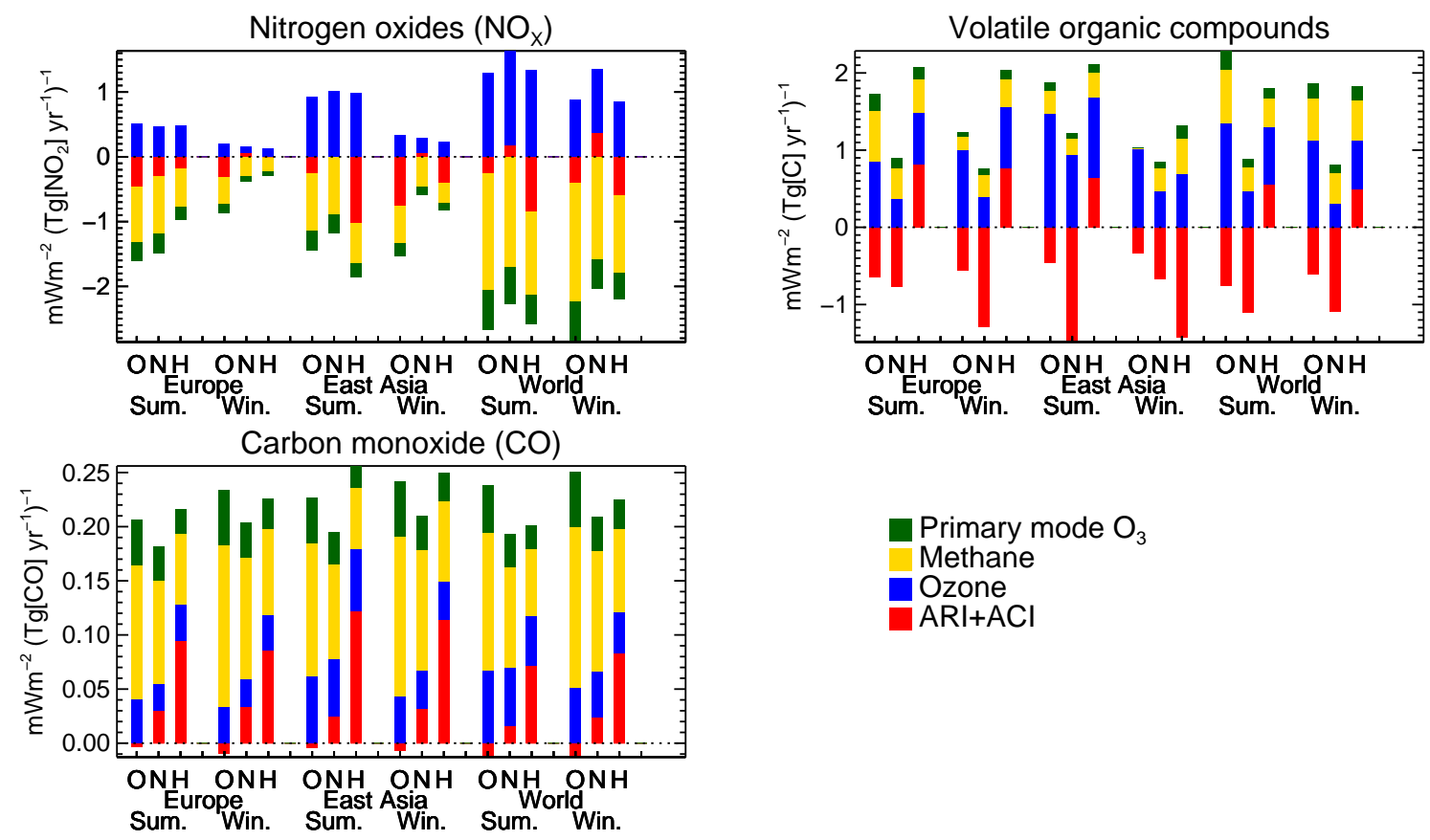

Primary mode $\mathrm{O}_{3}$ Methane

Ozone

$\mathrm{ARI}+\mathrm{ACl}$

Figure 4. Specific radiative forcing, in $\mathrm{mW} \mathrm{m}^{-2}\left(\mathrm{Tg} \mathrm{yr}^{-1}\right)^{-1}$, for regional and seasonal reductions in nitrogen oxide, volatile organic compounds, and carbon monoxide emissions. Results are obtained by three global models: OsloCTM2 (O), NorESM1 (N), and HadGEM3 (H). Four categories of radiative forcing mechanisms are included: aerosol-radiation and aerosol-cloud interactions (red), short-term changes in ozone (blue), methane (yellow), and primary-mode ozone (green).

monoxide perturbations in the three ECLIPSE models with tropospheric ozone chemistry schemes. The methane and primary-mode ozone SRF is calculated as global averages only, by multiplying the change in methane burden due to its reaction with $\mathrm{OH}$ by a methane RFE of $0.363 \mathrm{~mW} \mathrm{~m}^{-2} \mathrm{ppbv}^{-1}$ (Table 8.A.1 of Myhre et al., 2013a). Primary-mode ozone RFE is computed as the ratio of ozone RF to total methane burden change in the methane perturbation simulations (see Sect. 3.2). That RFE is more easily expressed as a fraction of methane RFE, with good agreement among ECLIPSE models: 0.396 for HadGEM3, 0.385 for NorESM1, and 0.395 for OsloCTM2.

For all models, regions, and seasons, total $\mathrm{NO}_{x} \mathrm{SRF}$ is negative and CO SRF is positive. Models disagree on the sign of VOC SRF. SRF components are region and season dependent, but the dependence of net SRF is less pronounced because the short-lived ozone and aerosol contributions compensate each other. Dependencies of CO SRFs on region and season are worth noting: an increased methane contribution makes winter perturbations more efficient at exerting a $\mathrm{CO}$ SRF than summer perturbations, and models also agree that East Asian perturbations exert slightly stronger SRFs than European perturbations because of a stronger SRF by ozone. East Asian ozone exerts a stronger RF per unit ozone burden because of higher $\mathrm{NO}_{x}$ background in that region but also because it is closer to the Equator, where more sunlight leads to a more active photochemistry (Berntsen et al., 2006).
In terms of RF contributions, models are in generally good agreement for the ozone contribution both on a global average (Fig. 4) and patterns (Figs. S9, S11, and S13), with ozone RF being mostly located in the latitude band of the perturbed region. The VOC perturbations are an exception and exhibit model diversity in global averages, echoing the complexity and diversity of VOC chemistry. Decreasing VOC emissions leads to a decrease in their oxidation products, $\mathrm{CO}$ and $\mathrm{O}_{3}$, therefore increasing $\mathrm{OH}$ and decreasing $\mathrm{CH}_{4}$ concentrations (Lin et al., 1988). Different VOCs have different photochemical $\mathrm{O}_{3}$ creation potentials (Derwent et al., 2001; Young et al., 2013). The three ECLIPSE models include a different number of VOC species. The model with the largest number of VOC species is OsloCTM2, with 40 species: 28 in the tropospheric chemistry scheme and 12 in the secondary organic aerosol scheme. Its broader range of VOC lifetimes and ozone production potentials means that it simulates the strongest ozone SRF. HadGEM3 is at the other end of the range of species considered and simulates the weakest ozone SRF. For CO, all models agree that the methane SRF contribution is larger than that of short-lived ozone changes. The opposite is true for VOC, where the ozone contribution dominates. This difference stems from the weaker ozone production potential of $\mathrm{CO}$, caused by slower reaction rates (e.g. Bowman, 1995).

There is a good agreement on methane and primary-mode ozone contributions between OsloCTM2 and NorESM1 but 
HadGEM3 simulates a weaker SRF. This is consistent with results from the methane perturbation (Sect. 3.2 and Table 7) and similarly caused by different baseline methane levels.

Models strongly disagree on the sign and magnitude of the aerosol contribution. For $\mathrm{NO}_{x}$, that contribution is generally negative, but NorESM1 also simulates positive contributions, especially in winter perturbations. OsloCTM2 and HadGEM3 disagree on the season and region where the strongest aerosol contributions are exerted. Figure S8 shows that those disagreements stem from differences in regional responses. Both HadGEM3 and NorESM1 show positive aerosol RFs centred on the regions being perturbed, caused by a decrease in sulfate aerosol formation through $\mathrm{OH}$ oxidation because $\mathrm{OH}$ levels are decreased. The $\mathrm{SO}_{2}$ that is not oxidised and not deposited is transported downwind of the perturbed region, where it promotes sulfate aerosol formation in the absence of oxidant limitation; in those regions, both models simulate negative aerosol RFs. The balance between regions of positive and negative aerosol RF varies depending on the model, the perturbed region, and the season. In contrast, OsloCTM2 does not simulate this dipole of responses: its aerosol contribution is negative almost everywhere on the globe. The representation of nitrate aerosols explains that difference of behaviour compared to the other models. Nitrate exerts between 50 and $95 \%$ of RFari to $\mathrm{NO}_{x}$ perturbations in OsloCTM2, with largest contributions in Northern Hemisphere winter months, adding a negative RF in, and downwind of, the perturbed regions. This brings the total aerosol $\mathrm{SRF}$ for $\mathrm{NO}_{x}$ perturbations firmly into negative values.

For VOC perturbations, the aerosol contribution is negative in NorESM1 and OsloCTM2 but generally positive in HadGEM3. VOC perturbations perturb aerosols via secondary organic aerosol formation. The strength of this link varies strongly between models because of the heterogeneity in the number and type of VOCs represented. Although HadGEM3 agrees with NorESM1 and OsloCTM2 that aerosol RF is negative above the perturbed regions (Fig. S10), those negative RFs are weak and therefore easily compensated on a global average by noisy positive contributions in regions where the aerosol internal mixture has been perturbed (e.g. north-western Russia, Indonesia, South America). Observational constraints on such internal mixture perturbations are lacking, so it is not currently possible to assess the realism of HadGEM3's response. The weakness of aerosol SRF in OsloCTM2 compared to NorESM1 is due to the representation of nitrate aerosols, which counteract part of the RF exerted by changes in sulfate aerosols, but also to a weaker RFaci contribution.

For CO perturbations, both NorESM1 and OsloCTM2 simulate relatively weak contributions of aerosols to $\mathrm{CO}$ SRF. The contribution simulated by OsloCTM2 is negative because the positive RFs exerted by sulfate and secondary organic aerosols are more than compensated by a negative RF by nitrate aerosols. HadGEM3 simulates a relatively strong response of aerosols to $\mathrm{CO}$ perturbations (Fig. S12), but that

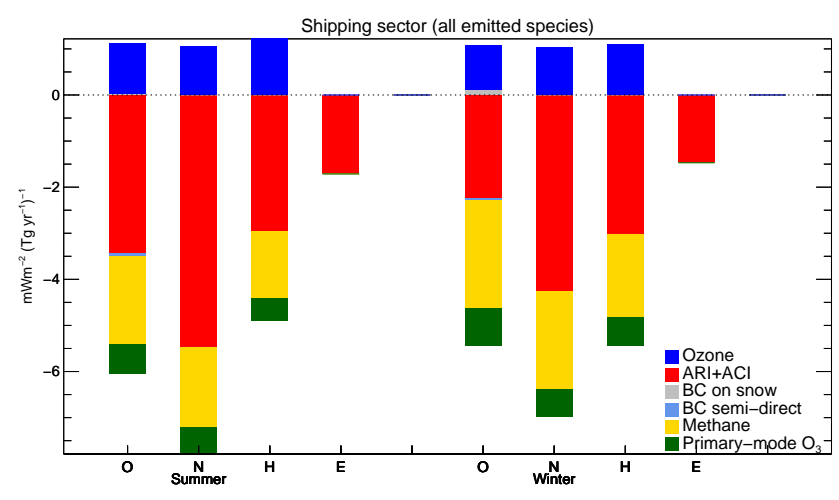

Figure 5. Specific radiative forcing, in $\mathrm{mW} \mathrm{m}^{-2}\left(\mathrm{Tg} \mathrm{yr}^{-1}\right)^{-1}$, for seasonal reductions in all the species emitted by the shipping sector. The species included and their units of emitted mass are sulfur dioxide $\left(\mathrm{SO}_{2}\right)$, black carbon $(\mathrm{BC})$, organic carbon $(\mathrm{C})$, ammonia $\left(\mathrm{NH}_{3}\right)$, nitrogen oxides $\left(\mathrm{NO}_{2}\right)$, volatile organic compounds (VOCs), carbon monoxide $(\mathrm{CO})$, and methane $\left(\mathrm{CH}_{4}\right)$. Results are obtained by four global models: OsloCTM2 (O), NorESM1 (N), HadGEM3 (H), and ECHAM6 (E). Six categories of radiative forcing mechanisms are included: aerosol-radiation and aerosol-cloud interactions (red, except for ECHAM6 which diagnoses aerosolradiation only), black carbon deposition on snow (grey, OsloCTM2 only), black carbon rapid adjustments from the semi-direct effect (light blue, OsloCTM2 only), short-term changes in ozone (dark blue, not simulated by ECHAM6), methane (yellow, not simulated by ECHAM6), and primary-mode ozone (green, not simulated by ECHAM6).

is because biomass-burning emissions were also perturbed in this model. NorESM1 and OsloCTM2 only perturbed fossilfuel combustion emissions, and the results suggest that links between $\mathrm{CO}$ and aerosols are stronger for biomass-burning sources. However, other sources of diversity, including the representation of atmospheric chemistry, could also explain the differences in behaviour between HadGEM3 and the other participating models.

\subsection{Shipping sector}

Figure 5 shows globally and annually averaged SRF for all species $\left(\mathrm{SO}_{2}, \mathrm{BC}, \mathrm{OC}, \mathrm{CH}_{4}, \mathrm{NO}_{x}, \mathrm{VOC}\right.$, and $\left.\mathrm{CO}\right)$ emitted by the shipping sector. ECHAM6 lacks a tropospheric ozone chemistry scheme, and therefore only simulates the aerosol contribution, and furthermore diagnoses RFari only. OsloCTM2 is the only model that includes BC-on-snow RF and quantifies BC semi-direct RF (Sect. 3.1). Models agree qualitatively that ozone contributes a positive SRF and methane, primary-mode ozone, and aerosols provide a negative SRF. Methane and primary-mode ozone SRFs, which are computed as described in Sect. 3.2, are mainly driven by emissions of $\mathrm{NO}_{x}$. The SRF contributed by short-lived changes in ozone are in good agreement among models, both in terms of global averages (Fig. 5) and geographical patterns (Fig. S16), with maxima in the tropics. ECLIPSE mod- 
els may overestimate that contribution, however, because assuming instantaneous dilution of emissions over their grid boxes, instead of representing ship plumes, is known to lead to an overestimate of ozone production by $\mathrm{NO}_{x}$ (Paoli et al., 2011). BC-on-snow (see also Fig. S15) and BC semi-direct $\mathrm{SRF}$, which are quantified from OsloCTM2 simulations as described in Sect. 3.2, are weak. Methane SRF is a large contribution to shipping SRF because ships emit in pristine environments, where ozone precursor emissions have a relatively larger impact than in polluted regions.

Models agree that aerosols dominate shipping SRF, but disagree on the strength of that contribution, for the same causes listed above, and notably different lifetimes, different strengths of RFaci, and different treatment of the aerosol mixing state. Geographical patterns are similar among models and reflect main shipping routes (Fig. S14). NorESM1 shows a region of positive aerosol RF in the Arctic, caused by the long-range transport of its long-lived $\mathrm{BC}$, which may not be realistic because that model overestimates BC Arctic concentrations in the summer (Eckhardt et al., 2015).

\section{Matrix of specific radiative forcing}

This section describes how the individual model results described in Sect. 3 can be summarised into the more useful best estimate and range. All global numbers by individual models are given in the Supplement to allow users to make other choices.

For each regional and seasonal perturbation by a NTCF, best estimates of SRF are provided for each RF mechanism: aerosols (sum of RFari and RFaci), BC deposition on snow, $\mathrm{BC}$ rapid adjustments to semi-direct effects, short-lived changes in tropospheric ozone concentrations, methane, and primary-mode ozone. The best estimate on net SRF is the sum of the best estimates of all RF mechanisms that are relevant to the NTCF considered. Inter-model diversity is represented by an interval ranging from the weaker SRF, obtained by adding the weaker estimates of all RF mechanisms, to the stronger SRF, obtained by adding the stronger estimates of all RF mechanisms. Best estimates of RF of BC deposition on snow and $\mathrm{BC}$ rapid adjustments from semi-direct effects are available from only one model, so they are also taken to represent high and low estimates. It is, however, important to note that the statistics on $\mathrm{BC}$ adjustments from semi-direct effects are not robust and that it may in fact not be significantly different from zero for the winter perturbations, as discussed in Sect. 3.1.

It can be argued that the models that fail to provide realistic simulations of key aspects of NTCF distributions and RF mechanisms should be discarded. For example, Shindell et al. (2013) screen the 10 models that participated in ACCMIP for their ability to reproduce observed total AOD and its recent trend, leading to a reduction in inter-model diversity. Such a screening is not applied here because models do not exhibit uniform skill at reproducing aerosol or ozone distributions; a model that could be considered best in one region often shows poorer skill in another. Nevertheless, decisions are required here on the inclusion of models that do not diagnose RFaci, simulate long BC lifetimes, lack nitrate aerosols, or simulate complex aerosol-chemistry responses. The decisions are as follows:

- For RFaci, ECHAM6 is not included in best estimates of aerosol SRF because it does not diagnose aci, which according to the other models is the often dominant contribution to total aerosol RF. It is possible that RFaci is in fact compensated by rapid adjustments in cloud liquid water path (e.g. Christensen and Stevens, 2011), meaning that ECLIPSE models overestimate the strength of aerosol SRF. However, there is currently no evidence that such compensation happens on a global scale.

- For BC lifetimes, a possible decision would be to discount models with $\mathrm{BC}$ lifetimes longer than about 4 days, which is the lifetime obtained by constraining $\mathrm{BC}$ mass concentration profiles with aircraft observations (Wang et al., 2014b; Hodnebrog et al., 2014). That decision would give more weight to the aerosol SRF simulated by ECHAM6 and HadGEM3. However, comparisons to surface observations in the Arctic suggest that ECHAM6 and HadGEM3 underestimate BC concentrations in that region (Eckhardt et al., 2015), perhaps because aerosols do not stay long enough in the atmosphere to be transported to the Arctic in those two models. Reconciling mixed conclusions from different indirect observational constraints on lifetime is therefore warranted. In the meantime, no model is discounted in this study when producing the best ECLIPSE model estimate and range of BC SRF. Still, the tendency of models to put $\mathrm{BC}$ too high in the atmosphere needs to be kept in mind, as it leads to an overestimated SRF.

- For nitrate, the descriptions of results for the $\mathrm{SO}_{2}$ (Sect. 3.1) and ozone precursor (Sect. 3.3) perturbations note the importance of co-variations in nitrate aerosols. Those are only represented in OsloCTM2 but are crucial in that model in determining the strength, and on occasions even the sign, of aerosol SRF. For that reason, it is decided here to add the nitrate SRF simulated by OsloCTM2 to the aerosol SRF of the other models. This solution is crude, as it is known that model diversity in simulating nitrate distributions is large (Myhre et al., 2013b) and a correlation between sulfate and nitrate RF can be expected from their links through ammonium. However, in the absence of a solid understanding of those correlations, the solution adopted here has the merit of simplicity and prevents misleading overcorrections.

- For aerosol-chemistry interactions, HadGEM3 simulates complex responses of aerosols to ozone precursor 

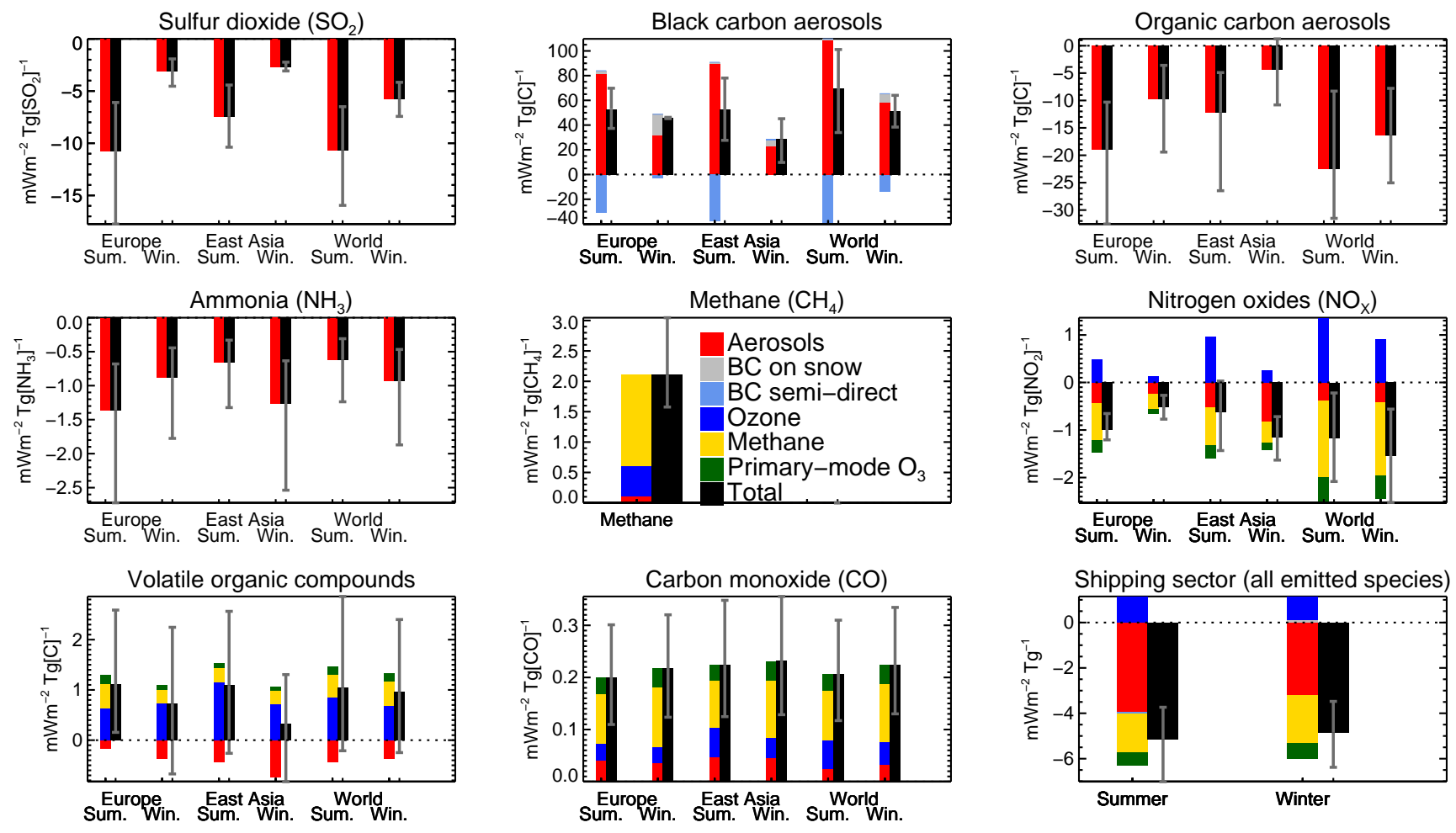

Figure 6. Best estimates of specific radiative forcing for regional and seasonal reductions in near-term climate forcer emissions, in $\mathrm{mW} \mathrm{m}^{-2}\left(\mathrm{Tg} \mathrm{yr}^{-1}\right)^{-1}$. Best estimates are given for six categories of radiative forcing: aerosol-radiation and aerosol-cloud interactions (red), black carbon deposition on snow (grey), black carbon rapid adjustments from semi-direct effects (light blue), short-term changes in ozone (dark blue), methane (yellow), and primary-mode ozone (green). Black bars show the total specific radiative forcing, i.e. the sum of the six components listed above, and whiskers denote the weakest and strongest specific radiative forcing that are obtained by the four participating models or, in the case of ammonia perturbations, estimated from the literature.

perturbations. This is particularly true of VOC perturbations (Sect. 3.3), where HadGEM3 simulates a positive SRF when NorESM1 and OsloCTM2 agree on a negative contribution. At this stage, the realism of HadGEM3's response cannot be confirmed by observations, nor can it be challenged. It is therefore decided to include HadGEM3 in the best estimate and range of VOC SRF, with the caveat that its behaviour is peculiar.

Figure 6 shows the resulting best SRF estimate for all perturbations. Best estimates for each mechanism are shown in colour. Best estimates for the net SRF are shown as black bars, with the range from weaker to stronger estimates represented as whiskers. The range for $\mathrm{NH}_{3}$ perturbations, which have been quantified from one model only, is assumed to be a factor 2 (Sect. 3.1). Model diversity ranges are often sizeable, but rarely include zero, indicating that models generally agree on the sign of the SRF of a given NTCF. The sign of the SRF exerted by VOC perturbations is, however, unclear because it depends on the strength and sign of aerosol responses, including secondary organic aerosols. The best estimate of VOC SRF is positive, but individual models cannot agree on the sign and the diversity range is large.
Quantitatively, best estimates of BC SRF are the strongest of all NTCFs, even after accounting for rapid adjustments from semi-direct effects. Aerosol SRFs are generally stronger than ozone precursor SRFs, with the exception of $\mathrm{NH}_{3}$ perturbations, which exert weak SRF because of competition with ammonium sulfate aerosol formation and because the diurnal cycle of nitrate aerosol formation is unfavourable to ari (Sect. 3.1). $\mathrm{NO}_{x}$ exerts the strongest SRF of all ozone precursor perturbations, although VOC perturbations are potentially as strong but much more uncertain. Shipping SRF is strong because of strong contributions by aerosols and methane.

The best estimates of this study are included in Table 1 for convenient comparison to previous studies. This study suggests a revision towards stronger $\mathrm{SRFs}$ for $\mathrm{SO}_{2}$ and OC perturbations because of the inclusion of RFaci. In contrast, this study's BC SRF is not very different from that derived by studies that consider ari only, because the inclusion of aci, deposition on snow, and rapid adjustments from semi-direct effects contributes only a weakly positive, and even at times negative, SRF. The BC SRF estimated in this study sits in the middle of the range proposed by Bond et al. (2013), in spite of their increase in emissions to correct for perceived 
underestimations in absorbing aerosol optical depth. This is because $\mathrm{BC}$ radiative efficiency for ari is fairly linear with emissions so SRF estimates are not strongly affected by BC emission changes. For methane and ozone precursor perturbation, the study agrees well with previous efforts in estimating the methane contribution. The SRF exerted by shortlived perturbations to ozone concentrations is generally revised upward. Compared to Fry (2012), this study quantifies aerosol responses to ozone precursor perturbations for more aerosol species and RF mechanisms, especially including aci. Those additional components put the aerosol contribution more firmly into negative values for $\mathrm{NO}_{x}$ and VOC perturbations, but with increased model diversity. For $\mathrm{CO}$ perturbations, Fry (2012), who only accounted for sulfate RFari, found that aerosols contributed a negative SRF. This study finds that contribution may in fact be positive because nitrate aerosols more than compensate for the sulfate RF.

\subsection{Seasonality}

For all perturbations, SRF best estimates are given for emission reductions applied in two periods, May-October and November-April, which are labelled in Fig. 6 as summer and winter, respectively, because emission perturbations are predominantly located in the Northern Hemisphere. The seasonality of methane perturbations was not considered because the time of emission becomes quickly irrelevant compared to the long residence time of methane in the atmosphere.

Aerosol primary and precursor perturbations are largely located in the Northern Hemisphere and summer emission reductions exert strong SRFs because the RF mechanisms act mostly on short-wave radiation. For RFari, anthropogenic aerosols are predominantly located in the accumulation mode, at sizes which interact most efficiently with shortwave radiation. For RFaci, changes to cloud albedo operate in the short-wave spectrum only, although BC semi-direct SRF has a long-wave component. In addition to RF mechanisms, chemical production and sinks (mainly from precipitation) also influence seasonality. $\mathrm{SO}_{2}$ photolysis is an example of a reaction favoured by higher, summertime, shortwave radiative fluxes. Temperature is also a factor, especially in nitrate aerosol formation, which is favoured by colder temperatures. This dependence explains the unusual seasonality of $\mathrm{NH}_{3}$ perturbations, which exert stronger SRFs in winter perturbations for East Asia and on a global average. The fact that European perturbations behave differently is linked to the lower sulfate aerosol levels in Europe, reducing their ability to limit nitrate formation in both summer and winter months.

The SRF of ozone precursor perturbations is exerted across both the short-wave and long-wave spectra, so its seasonality is not as strong as for aerosol perturbations and the details of ozone formation pathways are important. Figure 6 shows that winter $\mathrm{NO}_{x}$ perturbations exert stronger $\mathrm{SRFs}$, except for European perturbations. The seasonality of $\mathrm{NO}_{x}$
RF depends on the level of cancellation between the positive ozone contribution and the negative methane contribution. Derwent et al. (2008) found, by using a CTM, that there are no simple relationships that explain that competition, which also varies regionally. Our results replicate that complexity. $\mathrm{CO}$ winter perturbations are consistently stronger than summer perturbations, but differences are generally small. Finally, VOC perturbations may have a seasonality where summer perturbations are stronger than winter perturbations, but model diversity is large so the seasonality is uncertain.

\subsection{Latitudinal variations}

Figure 7a and $\mathrm{b}$ show best estimates and ranges of SRF for aerosols and ozone precursors, respectively, across four latitude bands: $90-60^{\circ} \mathrm{N}, 60-28^{\circ} \mathrm{N}, 28^{\circ} \mathrm{N}-28^{\circ} \mathrm{S}$, and $28-$ $90^{\circ} \mathrm{S}$. Those bands have been chosen to represent the Arctic, mid-latitudes, tropics, and Southern Hemisphere extratropical latitudes, respectively. The Southern Hemisphere is less resolved than the Northern Hemisphere because anthropogenic emissions are predominantly located in the latter. European emission perturbations are entirely located in the second band $\left(60-28^{\circ} \mathrm{N}\right)$. East Asian emission perturbations also include the northern portion of the third band $\left(28^{\circ} \mathrm{N}-\right.$ $28^{\circ} \mathrm{S}$ ). RotW and shipping perturbations are located across all four bands, but again with Northern Hemisphere emissions having more weight.

Latitudinal averaging of RF is done on the annual distributions shown as Supplement figures. SRF is then computed by normalising by the globally averaged emission change: so for a given perturbation, both global and latitudinal SRFs share the same normalisation factors. Annual distributions are, however, not available for methane $\mathrm{RF}$ and $\mathrm{BC}$ rapid adjustments to semi-direct effects. Methane RF has been computed as a global average only (see Sect. 3.2) because it is assumed here to be uniformly distributed across the globe, which is justified on an annual basis by the well-mixed nature of methane. BC rapid adjustments are associated with noisy distributions (see Sect. 3.1), so there is low confidence in the significance of regional patterns. They are assumed here to follow the same latitudinal distribution of BC RFari, which is justified by the close physical links between the two RF processes.

Figures 7 show that although SRF is typically stronger in the latitude band where the emission perturbation is applied, it is not confined to that latitude band. This behaviour is expected from atmospheric transport and has been found previously in other modelling studies (e.g. Shindell and Faluvegi, 2009). European aerosol and precursor perturbations affect the Arctic in a sizeable way. The BC European and global winter perturbations may even exert a stronger positive SRF in the Arctic than in mid-latitudes where the perturbations are located, because of the added positive contribution of BC-on-snow RF. The SRF exerted by East Asian perturbations is more confined to mid-latitudes because atmospheric 
(a)

\section{Sulfur dioxide perturbations}

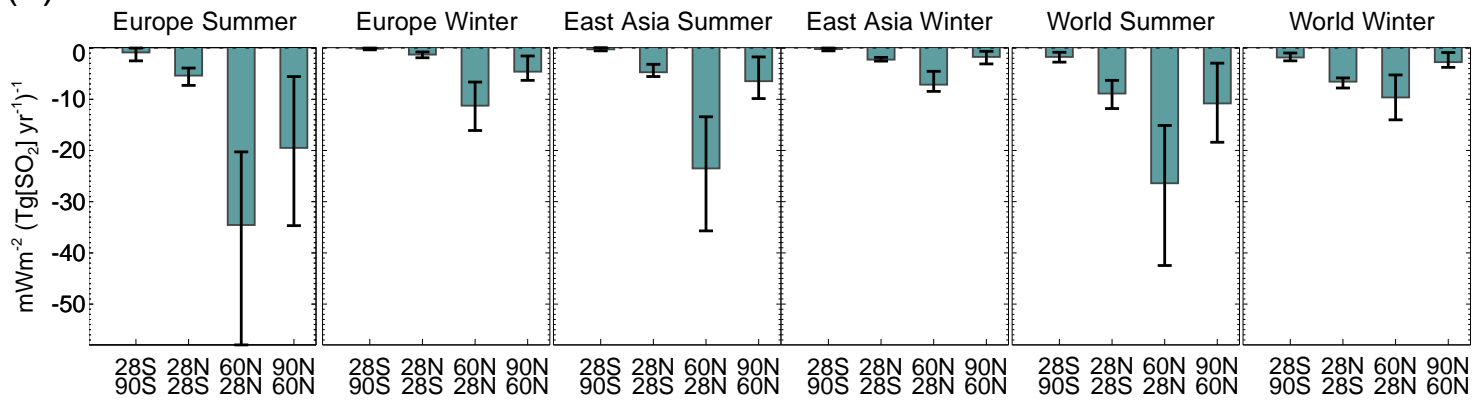

\section{Black carbon perturbations}
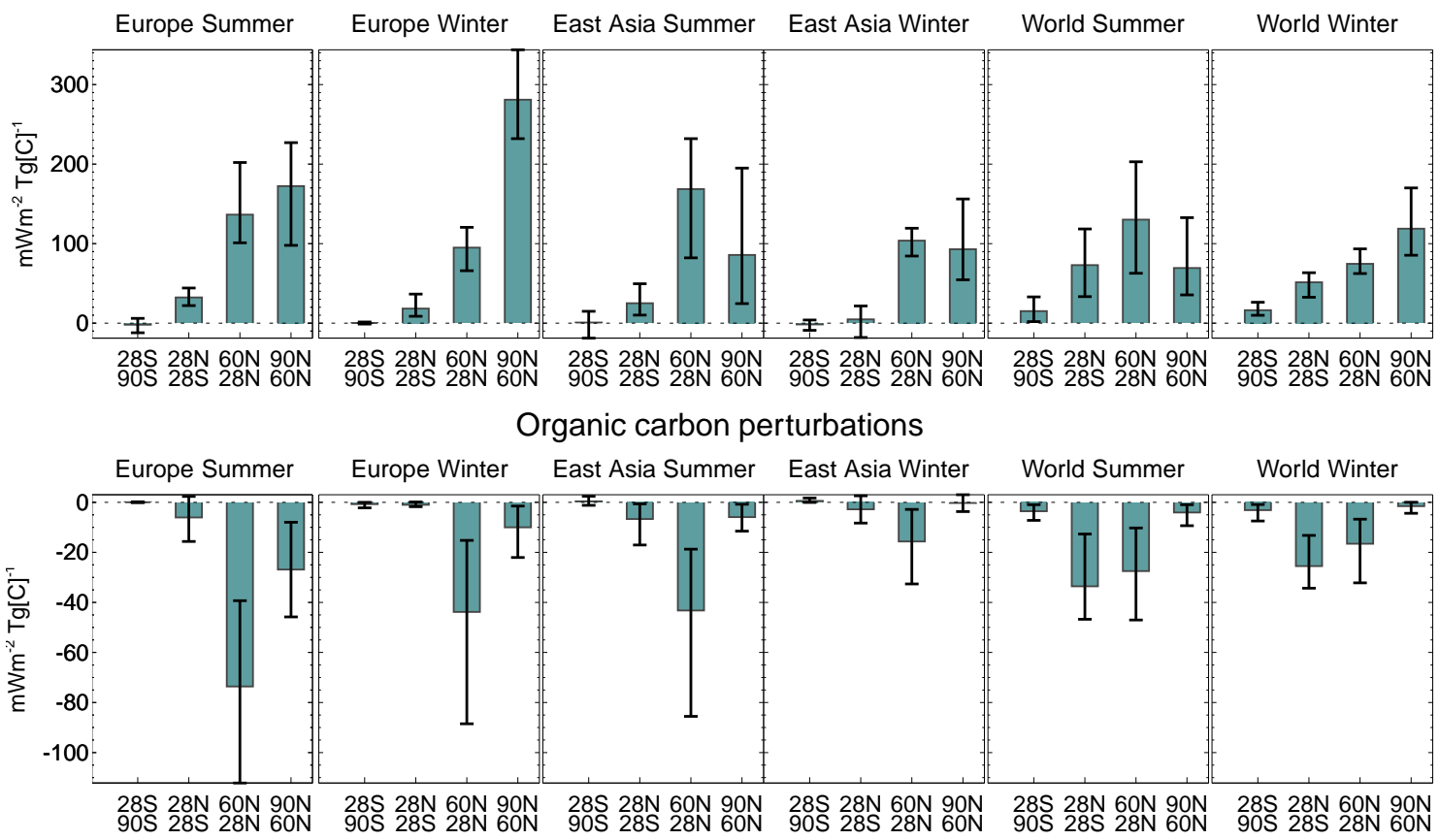

Ammonia perturbations

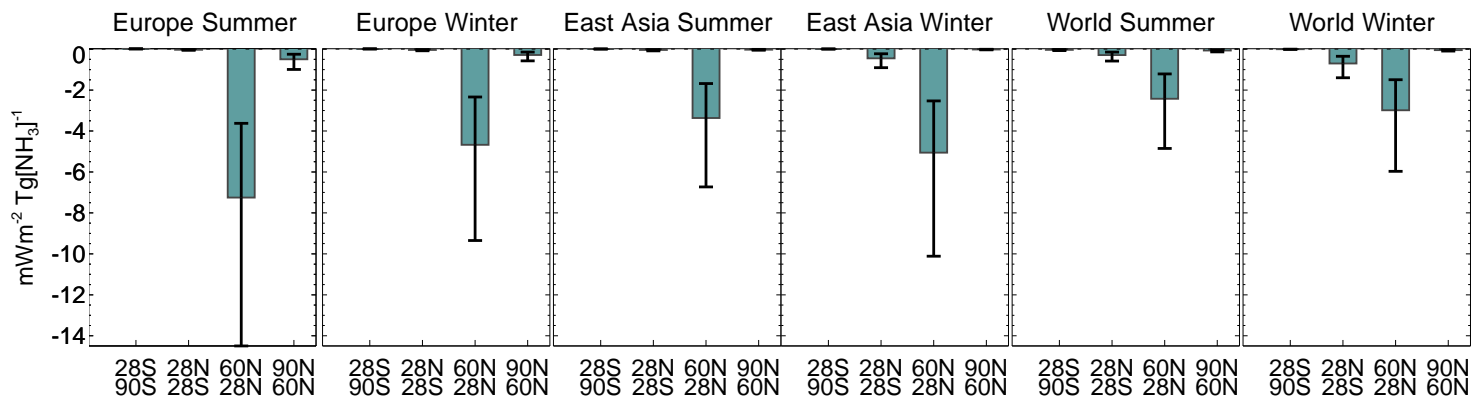

Figure 7.

transport preferentially advects the perturbations towards the Pacific Ocean rather than the Arctic, especially in winter perturbations (Fig. S2).

Ozone precursor perturbations (Fig. 7b) tend to be more diffuse than their aerosol counterparts, in part because of the longer lifetime of ozone in ECLIPSE models (Table 5) but also because perturbations to $\mathrm{OH}$ lifetime are more efficient in the tropics (Berntsen et al., 2006). SRF of ozone precursor perturbations are therefore strong in Northern Hemisphere mid-latitudes, where the perturbations are located, and the tropics. For European and East Asian perturbations, the Arctic is generally associated with weaker SRFs, except for CO, which is associated with more spatially uniform SRFs because methane RF is the main contributor. The SRF of ship- 
(b) Nitrogen dioxide perturbations

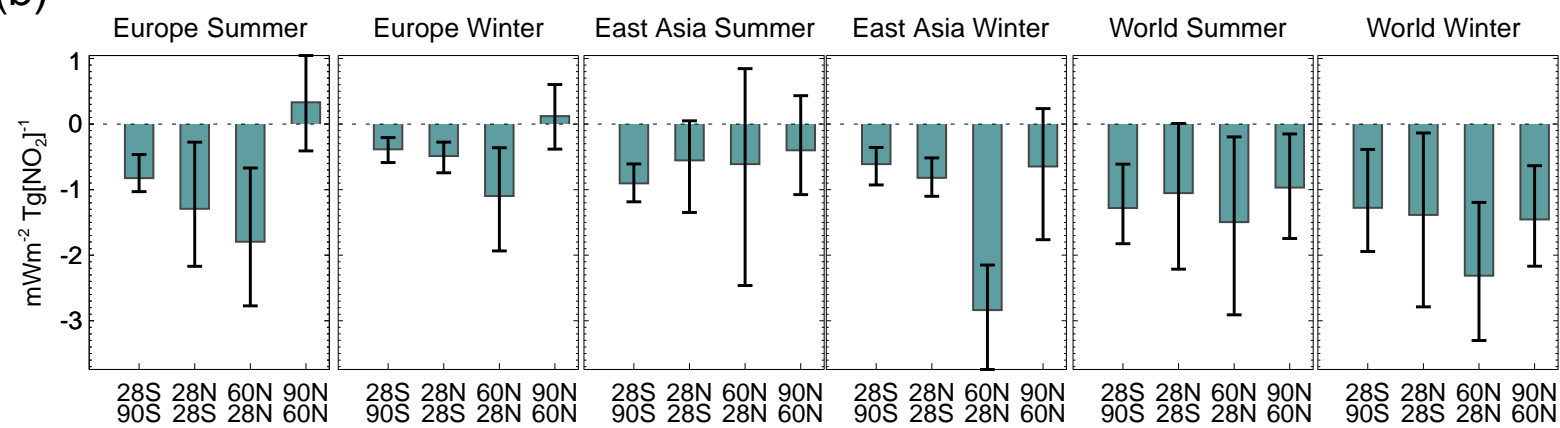

Volatile organic compounds perturbations

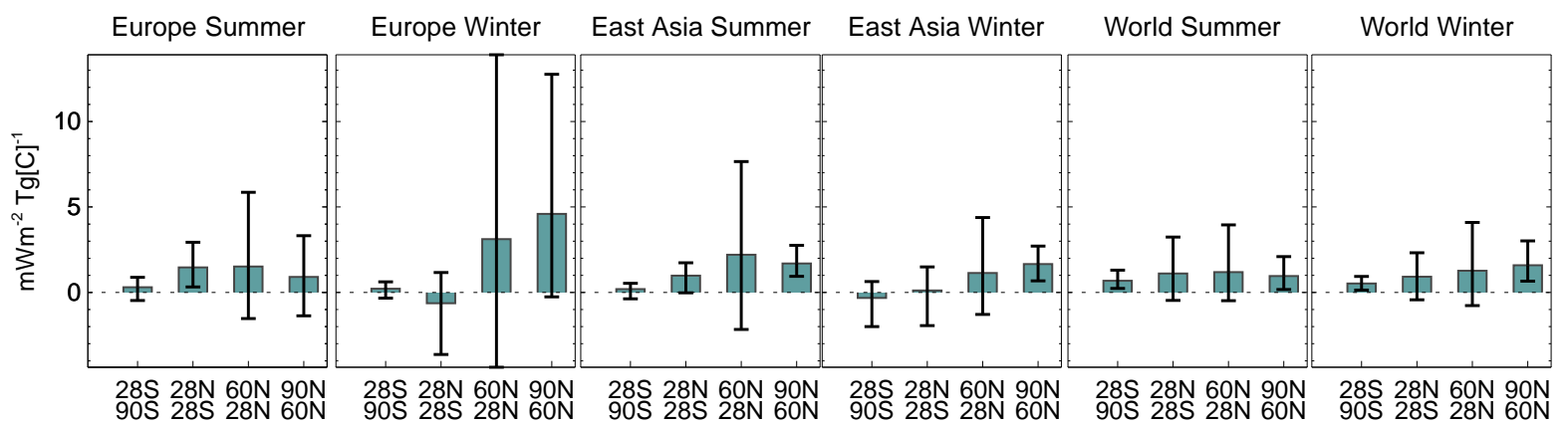

Carbon monoxide perturbations

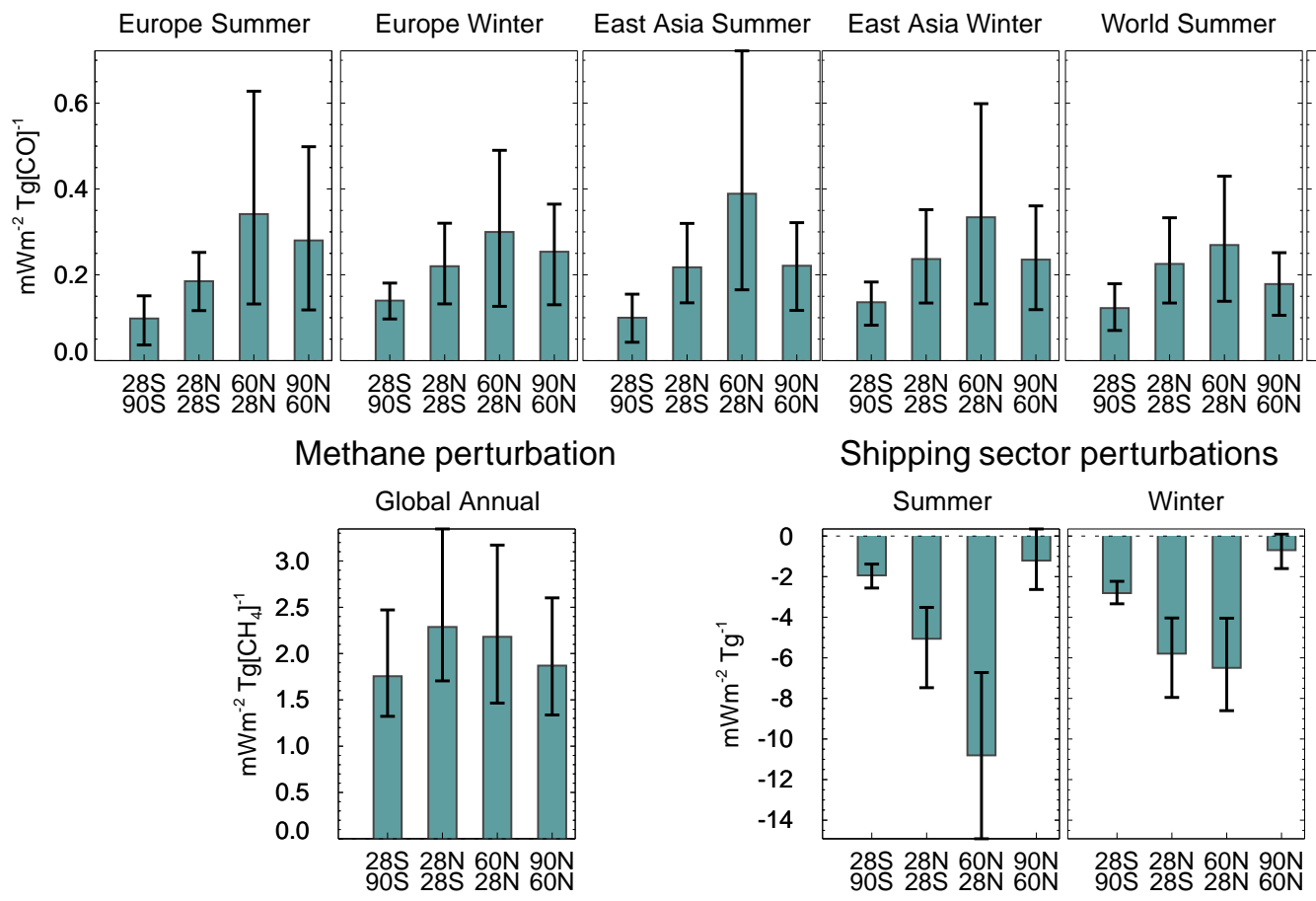

Figure 7. (a) Best estimates of annually averaged specific radiative forcing, in $\mathrm{mW} \mathrm{m}{ }^{-2}\left(\mathrm{Tg} \mathrm{yr}^{-1}\right)^{-1}$, in four latitude bands, for aerosol primary and precursor emission perturbations. Each row corresponds to a perturbed species: (from top to bottom) sulfur dioxide, black carbon, organic carbon, and ammonia. Each column corresponds to a regional and seasonal perturbation. Bar charts are shown for four latitude bands, from left to right: $90-60^{\circ} \mathrm{N}, 60-28^{\circ} \mathrm{N}, 28^{\circ} \mathrm{N}-28^{\circ} \mathrm{S}$, and $28-90^{\circ} \mathrm{S}$. (b) As Fig. 7a but for ozone precursor and shipping sector perturbations. Perturbed species are, from top to bottom, nitrogen oxide, volatile organic compounds, carbon monoxide, methane, and all species emitted by the shipping sector. 
ping sector perturbations peaks in the Northern Hemisphere, where the busiest shipping lanes are located.

\section{Conclusions}

This study provides NTCF SRFs by using ECLIPSE model simulations by four general circulation and chemistrytransport models: ECHAM6, HadGEM3, NorESM1, and OsloCTM2. SRFs are given for eight NTCFs, four regions or sectors, and six RF mechanisms. The four regions are Europe, East Asia, global average, and the shipping sector. The eight NTCFs or NTCF precursors are $\mathrm{SO}_{2}, \mathrm{BC}, \mathrm{OC}$, $\mathrm{NH}_{3}$, methane, $\mathrm{NO}_{x}, \mathrm{CO}$, and VOC. $\mathrm{NH}_{3}$ perturbations were applied in OsloCTM2 only, which includes a representation of nitrate aerosols. The six RF mechanisms are aerosols (both ari and aci), $\mathrm{BC}$ deposition on snow, $\mathrm{BC}$ rapid adjustments from semi-direct effects, short-lived ozone changes, methane, and primary-mode ozone. OsloCTM2 is the only model used to estimate $\mathrm{BC}$ deposition on snow and $\mathrm{BC}$ rapid adjustments from semi-direct effects. ECHAM6 does not simulate ozone chemistry and so does not provide SRFs for the last three RF mechanisms on the list.

Models generally agree on the sign of the total SRF of a given NTCF, except for VOC, although its best estimate is positive. Quantitatively, models are more diverse. That diversity has multiple and complex roots, but four important aspects stand out.

- Diversity in modelled NTCF lifetimes is large, with longest lifetimes being 1.5 to 2.5 times longer than the shortest lifetimes depending on NTCF. Differences in lifetime affect both the reach of long-range transport and the reference baseline.

- The unperturbed baseline causes diversity for non-linear RF mechanisms, such as RFaci and methane RF. It is also a common cause for regional differences in SRF.

- The number of species represented varies among models. Nitrate and secondary aerosols modulate the strength of the SRF exerted by $\mathrm{SO}_{2}, \mathrm{NO}_{x}, \mathrm{VOC}$, and $\mathrm{CO}$ perturbations but are not included in all models, causing potentially misleading results in models where those aerosol species are absent. Models that include VOC emissions also account for a different number and type of VOC species.

- Interactions between aerosols and chemistry, and particularly aerosol responses to changes in the oxidising capacity of the atmosphere and secondary organic aerosol formation, affect the strength, possibly even the sign, and the seasonality of SRF. The strength of those interactions differs among models.

Harmonising modelling capabilities and deriving observational constraints on modelled lifetimes (e.g. Kristiansen et al., 2016) and responses of $\mathrm{OH}$ concentrations to chemistry perturbations will be useful in reducing model diversity while also quantifying model skill at simulating atmospheric composition with fidelity. Other causes of diversity include different aerosol optical properties, including BC absorbing properties (e.g. Myhre et al., 2013b); different vertical profiles (e.g. Samset et al., 2013); different cloud processes, which affect the strength of RFaci (e.g. Quaas et al., 2009); and host model considerations, such as the use of different radiative transfer schemes (Stier et al., 2013) and different simulations of horizontal and vertical cloud distributions.

From a climate mitigation point of view, the key messages from the present study are as follows:

- Including aerosol-cloud interactions increases the magnitude of the SRF for $\mathrm{SO}_{2}$ and $\mathrm{OC}$ perturbations compared to previous studies. The NTCFs exerting the strongest SRFs are well identified, with robust rankings across models. SRF exerted by aerosol perturbations is up to an order of magnitude stronger than methane and ozone precursor perturbations, although the latter are associated with larger emission rates.

- Perturbing VOC emissions is an unreliable mitigation option because different models disagree on the sign of the resulting SRF.

- It is more efficient to perturb European or shipping aerosol emissions than East Asian emissions because East Asia has a more polluted baseline which saturates RFaci and dampens the impact of emission reductions. So improving air quality without weakening the negative RF of aerosols is easier in the more polluted regions. The regional dependence of ozone precursor SRF is more complex, and no systematic rule is found, in common with previous studies (Derwent et al., 2008). The regional dependencies of CO perturbations are, however, weaker than those of $\mathrm{NO}_{x}$ and VOC, as also found by Fry (2012).

- SRFs generally peak in the latitude band where the perturbation is applied, although other regions, notably the Arctic, are affected through long-range transport. In that respect, reducing European BC winter emissions seems an efficient way to minimise positive RF in the Arctic because of the added contribution of $\mathrm{BC}$ deposition on snow.

- The SRF of summer perturbations is stronger than that of winter perturbations for most NTCFs, with the notable exception of ammonia perturbations. The SRF seasonality of aerosol perturbations is more pronounced than that of ozone precursor perturbations and less complex and regionally dependent. Minimising positive anthropogenic RF by NTCF mitigation is thus best done by reducing summertime emissions of species with 
positive SRFs, like BC, and wintertime emissions of species with negative SRFs, like $\mathrm{SO}_{2}$.

Aamaas et al. (2016) provide an example of how the ECLIPSE matrix of SRF can be used to derive climate metrics able to estimate the climate impact of mitigation policies. Baker et al. (2015) discuss the climate impacts simulated by climate models forced by future emission scenarios based on the ECLIPSE SRF matrix, concluding that the climate response to reductions of $\mathrm{BC}$ and $\mathrm{OC}$ emissions is not clearly discernible.

The SRF matrix presented does not include rapid adjustments to all RF mechanisms and so is not a matrix of specific ERF, which would arguably have been more useful. Unfortunately, quantifying ERF is more challenging than the already challenging task of quantifying $\mathrm{RF}$, especially for the small regional and seasonal perturbations considered here. The challenge is to distinguish, in a statistically robust way, rapid adjustments from internal variability. The only rapid adjustment considered in this study is from the semi-direct effect of $\mathrm{BC}$ aerosols, and the statistics are fragile. Nudging of temperature and wind speeds has shown promise in decreasing the size of internal variability (Kooperman et al., 2012), but whether that method also suppresses rapid adjustments is unknown. One possible variation of that method is to allow temperature to adjust freely to semi-direct effects, while wind speeds remain nudged to decrease internal variability between perturbed and unperturbed simulations. Implemented in HadGEM3, that method successfully reproduces the globally averaged seasonality of ERF and subsequent precipitation changes simulated by free-running simulations (Figs. S17 and S18). The simulations required to do so are 6 times shorter and have better statistics. This encouraging result holds for a variety of RF mechanisms, including a doubling of carbon dioxide concentrations and RF ari and aci. However, that method assumes that thermodynamical and dynamical responses are separated, at least over rapid adjustment timescales, which remains to be demonstrated.

\section{Data availability}

The Supplement includes spreadsheets giving globally averaged numbers for all perturbation simulations and radiative forcing mechanisms, by all models.

\section{The Supplement related to this article is available online at doi:10.5194/acp-16-13885-2016-supplement.}

Author contributions. Nicolas Bellouin, Gunnar Myhre, and Johannes Quaas designed the experiments as part of the ECLIPSE project. Nicolas Bellouin, Laura Baker, Øivind Hodnebrog, Dirk Olivié, Ribu Cherian, Claire Macintosh, Bjørn Samset, and
Anna Esteve ran the experiments or radiative transfer calculations and analysed the datasets. Borgar Aamaas provided additional data analysis in the perspective of climate metrics users. Nicolas Bellouin prepared the manuscript with contributions from all co-authors.

Acknowledgements. The research and simulations described in this study were funded by the European Union Seventh Framework Programme (FP7/2007-2013) under grant agreement number 282688 - ECLIPSE. The research team based at the University of Reading acknowledges use of the MONSooN supercomputing system, a collaborative facility supplied under the Joint Weather and Climate Research Programme, which is a strategic partnership between the UK Met Office and the UK Natural Environment Research Council. The University of Leipzig team acknowledges additional funding by the European Research Council (QUAERERE, GA 306284) and computing time from the German Climate Computing Centre (DKRZ). The CICERO team acknowledges additional funding from the Research Council of Norway through the NetBC (number 244141) and SLAC (number 208277) projects

Edited by: H. Tost

Reviewed by: two anonymous referees

\section{References}

Aamaas, B., Berntsen, T. K., Fuglestvedt, J. S., Shine, K. P., and Bellouin, N.: Regional emission metrics for short-lived climate forcers from multiple models, Atmos. Chem. Phys., 16, 74517468, doi:10.5194/acp-16-7451-2016, 2016.

Baker, L. H., Collins, W. J., Olivié, D. J. L., Cherian, R., Hodnebrog, Ø., Myhre, G., and Quaas, J.: Climate responses to anthropogenic emissions of short-lived climate pollutants, Atmos. Chem. Phys., 15, 8201-8216, doi:10.5194/acp-15-8201-2015, 2015.

Bellouin, N., Rae, J., Jones, A., Johnson, C., Haywood, J., and Boucher, O.: Aerosol forcing in the Climate Model Intercomparison Project (CMIP5) simulations by HadGEM2-ES and the role of ammonium nitrate, J. Geophys. Res., 116, D20206, doi:10.1029/2011JD016074, 2011.

Berntsen, T., Fuglestvedt, J., Myhre, G., Stordal, F., and Berglen T. F.: Abatement of Greenhouse Gases: Does Location Matter?, Climatic Change, 74, 377-411, doi:10.1007/s10584-006-0433-4, 2006.

Bentsen, M., Bethke, I., Debernard, J. B., Iversen, T., Kirkevåg, A., Seland, Ø., Drange, H., Roelandt, C., Seierstad, I. A., Hoose, C., and Kristjánsson, J. E.: The Norwegian Earth System Model, NorESM1-M - Part 1: Description and basic evaluation of the physical climate, Geosci. Model Dev., 6, 687-720, doi:10.5194/gmd-6-687-2013, 2013.

Bond, T. C., Doherty, S. J., Fahey, D. W., Forster, P. M., Berntsen, T., DeAngelo, B. J., Flanner, M. G., Ghan, S., Kärcher, B., Koch, D., Kinne, S., Kondo, Y., Quinn, P. K., Sarofim, M. C., Schultz, M. G., Schulz, M., Venkataraman, C., Zhang, H., Zhang, S., Bellouin, N., Guttikunda, S. K., Hopke, P. K., Jacobson, M. Z., Kaiser, J. W., Klimont, Z., Lohmann, U., Schwarz, J. P., Shindell, D., Storelvmo, T., Warren, S. G., and Zender, 
C. S.: Bounding the role of black carbon in the climate system: A scientific assessment, J. Geophys. Res., 118, 5380-5552, doi:10.1002/jgrd.50171, 2013.

Boucher, O., Randall, D., Artaxo, P., Bretherton, C., Feingold, G., Forster, P., Kerminen, V.-M., Kondo, Y., Liao, H., Lohmann, U., Rasch, P., Satheesh, S. K., Sherwood, S., Stevens, B., and Zhang, X. Y.: Clouds and Aerosols, in: Climate Change 2013: The Physical Science Basis, Contribution of Working Group I to the Fifth Assessment Report of the Intergovernmental Panel on Climate Change edited by: Stocker, T. F., Qin, D., Plattner, G.-K., Tignor, M., Allen, S. K., Boschung, J., Nauels, A.,, Xia, Bex, V., and Midgley, P. M., Cambridge University Press, Cambridge, United Kingdom and New York, NY, USA, 2013.

Bowman, F. M.: A multi-parent assignment method for analyzing atmospheric chemistry mechanisms, Atmos. Environ., 39, 25192533, doi:10.1016/j.atmosenv.2004.12.040, 2005.

Brioude, J., Cooper, O. R., Feingold, G., Trainer, M., Freitas, S. R., Kowal, D., Ayers, J. K., Prins, E., Minnis, P., McKeen, S. A., Frost, G. J., and Hsie, E.-Y.: Effect of biomass burning on marine stratocumulus clouds off the California coast, Atmos. Chem. Phys., 9, 8841-8856, doi:10.5194/acp-9-8841-2009, 2009.

Carslaw, K. S., Lee, L. A., Reddington, C. L., Pringle, K. J., Rap, A., Forster, P. M., Mann, G. W., Spracklen, D. V., Woodhouse, M. T., Regayre, L. A., and Pierce, J. R.: Large contribution of natural aerosols to uncertainty in indirect forcing, Nature, 503, 67-71, doi:10.1038/nature12674, 2013.

Christensen, M. W. and Stephens, G. L.: Microphysical and macrophysical responses of marine stratocumulus polluted by underlying ships: Evidence of cloud deepening, J. Geophys. Res., 116, D03201, doi:10.1029/2010JD014638, 2011.

Collins, W. D.: Parameterization of generalized cloud overlap for radiative calculations in general circulation models, J. Atmos. Sci., 58, 3224-3242, doi:10.1175/15200469(2001)058<3224:POGCOF>2.0.CO;2, 2001.

Dall'Osto, M., Harrison, R. M., Coe, H., Williams, P. I., and Allan, J. D.: Real time chemical characterization of local and regional nitrate aerosols, Atmos. Chem. Phys., 9, 3709-3720, doi:10.5194/acp-9-3709-2009, 2009.

Dalsøren, S. B., Endresen, Ø., Isaksen, I. S. A., Gravir, G., and Sørgård, E.: Environmental impacts of the expected increase in sea transportation, with a particular focus on oil and gas scenarios for Norway and northwest Russia, J. Geophys. Res., 112, D02310, doi:10.1029/2005JD006927, 2007.

Derwent, R. G., Jenkin, M. E., Saunders, S. M., and Pilling, M. J.: Characterization of the reactivities of volatile organic compounds using a master chemical mechanism, J. Air Waste Manage., 51, 699-707, doi:10.1080/10473289.2001.10464297, 2001.

Derwent, R. G., Stevenson, D. S., Doherty, R. M., Collins, W. J., Sanderson, M. G., and Johnson, C. E.: Radiative forcing from surface $\mathrm{NO}_{x}$ emissions: spatial and seasonal variations, Climatic Change, 88, 385-401, doi:10.1007/s10584-007-9383-8, 2008.

Dubovik, O., Smirnov, A., Holben, B. N., King, M. D., Kaufman, Y. J., Eck, T. F., and Slutsker, I.: Accuracy assessment of aerosol optical properties retrieval from AERONET sun and sky radiance measurements, J. Geophys. Res., 105, 9791-9806, 2000.

Eckhardt, S., Quennehen, B., Olivié, D. J. L., Berntsen, T. K., Cherian, R., Christensen, J. H., Collins, W., Crepinsek, S., Daskalakis, N., Flanner, M., Herber, A., Heyes, C., Hodnebrog, Ø., Huang, L., Kanakidou, M., Klimont, Z., Langner, J., Law,
K. S., Lund, M. T., Mahmood, R., Massling, A., Myriokefalitakis, S., Nielsen, I. E., Nøjgaard, J. K., Quaas, J., Quinn, P. K., Raut, J.-C., Rumbold, S. T., Schulz, M., Sharma, S., Skeie, R. B., Skov, H., Uttal, T., von Salzen, K., and Stohl, A.: Current model capabilities for simulating black carbon and sulfate concentrations in the Arctic atmosphere: a multi-model evaluation using a comprehensive measurement data set, Atmos. Chem. Phys., 15, 9413-9433, doi:10.5194/acp-15-9413-2015, 2015.

Edwards, J. and Slingo, A.: Studies with a flexible new radiation code, I: Choosing a cofiguration for a large-scale model, Q. J. Roy. Meteor. Soc., 122, 689-719, 1996.

Emmons, L. K., Walters, S., Hess, P. G., Lamarque, J.-F., Pfister, G. G., Fillmore, D., Granier, C., Guenther, A., Kinnison, D., Laepple, T., Orlando, J., Tie, X., Tyndall, G., Wiedinmyer, C., Baughcum, S. L., and Kloster, S.: Description and evaluation of the Model for Ozone and Related chemical Tracers, version 4 (MOZART-4), Geosci. Model Dev., 3, 43-67, doi:10.5194/gmd3-43-2010, 2010.

Fiore, A. M., Naik, V., and Leibensperger, E. M.: Air quality and climate connections, J. Air Waste Manage., 65, 645-685, doi:10.1080/10962247.2015.1040526, 2015.

Fry, M. M.: The influence of ozone precursor emissions from four world regions on tropospheric composition and radiative climate forcing, J. Geophys. Res., 117, D07306, doi:10.1029/2011JD017134, 2012.

Fujino, J., Nair, R., Kainuma, M., Masui, T., and Matsuoka, Y.: Multigas mitigation analysis on stabilization scenarios using AIM global model, Energy J., 3, 343-354, 2006.

Fuglestvedt, J. S., Shine, K. P., Cook, J., Berntsen, T., Lee, D. S., Stenke, A., Bieltvedt Skeie, R., Velders, G., and Waitz, I.: Transport Impacts on Atmosphere and Climate: Metrics, Atmos. Environ., 44, 4648-4677, 2010.

Gadhavi, H. S., Renuka, K., Ravi Kiran, V., Jayaraman, A., Stohl, A., Klimont, Z., and Beig, G.: Evaluation of black carbon emission inventories using a Lagrangian dispersion model - a case study over southern India, Atmos. Chem. Phys., 15, 1447-1461, doi:10.5194/acp-15-1447-2015, 2015.

Ghan, S. J.: Technical Note: Estimating aerosol effects on cloud radiative forcing, Atmos. Chem. Phys., 13, 9971-9974, doi:10.5194/acp-13-9971-2013, 2013.

Hauglustaine, D. A., Balkanski, Y., and Schulz, M.: A global model simulation of present and future nitrate aerosols and their direct radiative forcing of climate, Atmos. Chem. Phys., 14, 1103111063, doi:10.5194/acp-14-11031-2014, 2014.

Hegg, D. A.: Cloud condensation nucleus-sulphate mass relationship and cloud albedo, J. Geophys. Res., 99, 25903-25907, doi:10.1029/94JD02224, 1994.

Hewitt, H. T., Copsey, D., Culverwell, I. D., Harris, C. M., Hill, R. S. R., Keen, A. B., McLaren, A. J., and Hunke, E. C.: Design and implementation of the infrastructure of HadGEM3: the nextgeneration Met Office climate modelling system, Geosci. Model Dev., 4, 223-253, doi:10.5194/gmd-4-223-2011, 2011.

Hodnebrog, $\varnothing$, Myhre, G., and Samset, B. H.: How shorter black carbon lifetime alters its climate effect, Nat. Commun., 5, 5065, doi:10.1038/ncomms6065, 2014.

Holmes, C. D., Prather, M. J., Søvde, O. A., and Myhre, G.: Future methane, hydroxyl, and their uncertainties: key climate and emission parameters for future predictions, Atmos. Chem. Phys., 13, 285-302, doi:10.5194/acp-13-285-2013, 2013. 
Iacono, M. J., Delamere, J. S., Mlawer, E. J., Shephard, M. W., Clough, S. A., and Collins, W. D.: Radiative forcing by long-lived greenhouse gases: Calculations with the AER radiative transfer models, J. Geophys. Res., 113, D13103, doi:10.1029/2008JD009944, 2008.

Iversen, T., Bentsen, M., Bethke, I., Debernard, J. B., Kirkevåg, A., Seland, Ø., Drange, H., Kristjansson, J. E., Medhaug, I., Sand, M., and Seierstad, I. A.: The Norwegian Earth System Model, NorESM1-M - Part 2: Climate response and scenario projections, Geosci. Model Dev., 6, 389-415, doi:10.5194/gmd-6-3892013, 2013.

Jiang, J. H., Su, H., Zhai, C., Perun, V., Del Genio, A. D., Nazarenko, L. S., Donner, L. J., Horowitz, L. W., Seman, C. J., Cole, J., Gettelman, A., Ringer, M. A., Rotstayn, L. D., Jeffrey, S. J., Wu, T., Brient, F., Dufresne, J.-L., Kawai, H., Koshiro, T., Masahiro, W., L'Écuyer, T. S., Volodin, E. M., Iversen, T., Drange, H., dos Santos Mesquita, M., Read, W. G., Waters, J. W., Tian, B., Teixeira, J., and Stephens, G. L.: Evaluation of cloud and water vapor simulations in CMIP5 climate models using NASA “A-Train" satellite observations, J. Geophys. Res., 117, D14105, doi:10.1029/2011JD017237, 2012.

Jiao, C., Flanner, M. G., Balkanski, Y., Bauer, S. E., Bellouin, N., Berntsen, T. K., Bian, H., Carslaw, K. S., Chin, M., De Luca, N., Diehl, T., Ghan, S. J., Iversen, T., Kirkevåg, A., Koch, D., Liu, X., Mann, G. W., Penner, J. E., Pitari, G., Schulz, M., Seland, Ø., Skeie, R. B., Steenrod, S. D., Stier, P., Takemura, T., Tsigaridis, K., van Noije, T., Yun, Y., and Zhang, K.: An AeroCom assessment of black carbon in Arctic snow and sea ice, Atmos. Chem. Phys., 14, 2399-2417, doi:10.5194/acp-14-2399-2014, 2014.

Jones, A., Roberts, D. L., and Slingo, A. A: climate model study of indirect radiative forcing by anthropogenic sulphate aerosols, Nature, 370, 450-453, 1994.

Kirkevåg, A., Iversen, T., Seland, Ø., Hoose, C., Kristjánsson, J. E., Struthers, H., Ekman, A. M. L., Ghan, S., Griesfeller, J., Nilsson, E. D., and Schulz, M.: Aerosol-climate interactions in the Norwegian Earth System Model - NorESM1-M, Geosci. Model Dev., 6, 207-244, doi:10.5194/gmd-6-207-2013, 2013.

Koch, D. and Del Genio, A. D.: Black carbon semi-direct effects on cloud cover: review and synthesis, Atmos. Chem. Phys., 10, 7685-7696, doi:10.5194/acp-10-7685-2010, 2010.

Koffi, B., Schulz, M., Breon, F. M., Dentener, F., Steensen, B. M., Griesfeller, J., Winker, D., Balkanski, Y., Bauer, S.E., Bellouin, N., Berntsen, T., Bian, H. S., Chin, M., Diehl, T., Easter, R., Ghan, S., Hauglustaine, D. A., Iversen, T., Kirkevag, A., Liu, X.H., Lohmann, U., Myhre, G., Rasch, P., Seland, O., Skeie, R. B., Steenrod, S. D., Stier, P., Tackett, J., Takemura, T., Tsigaridis, K., Vuolo, M. R., Yoon, J., and Zhang, K.: Evaluation of the aerosol vertical distribution in global aerosol models through comparison against CALIOP measurements: AeroCom phase II results, J. Geophys. Res., 121, 7254-7283, doi:10.1002/2015JD024639, 2016.

Kooperman, G. J., Pritchard, M. S., Ghan, S. J., Wang, M., Somerville, R. C. J., and Russell, L. M.: Constraining the influence of natural variability to improve estimates of global aerosol indirect effects in a nudged version of the Community Atmosphere Model 5, J. Geophys. Res., 117, D23204, doi:10.1029/2012JD018588, 2012.

Kristiansen, N. I., Stohl, A., and Wotawa, G.: Atmospheric removal times of the aerosol-bound radionuclides ${ }^{137} \mathrm{Cs}$ and ${ }^{131} \mathrm{I}$ mea- sured after the Fukushima Dai-ichi nuclear accident - a constraint for air quality and climate models, Atmos. Chem. Phys., 12, 10759-10769, doi:10.5194/acp-12-10759-2012, 2012.

Kristiansen, N. I., Stohl, A., Olivié, D. J. L., Croft, B., Søvde, O. A., Klein, H., Christoudias, T., Kunkel, D., Leadbetter, S. J., Lee, Y. H., Zhang, K., Tsigaridis, K., Bergman, T., Evangeliou, N., Wang, H., Ma, P.-L., Easter, R. C., Rasch, P. J., Liu, X., Pitari, G., Di Genova, G., Zhao, S. Y., Balkanski, Y., Bauer, S. E., Faluvegi, G. S., Kokkola, H., Martin, R. V., Pierce, J. R., Schulz, M., Shindell, D., Tost, H., and Zhang, H.: Evaluation of observed and modelled aerosol lifetimes using radioactive tracers of opportunity and an ensemble of 19 global models, Atmos. Chem. Phys., 16, 3525-3561, doi:10.5194/acp-16-3525-2016, 2016.

Lacis, A. A., Wuebbles, D. J., and Logan, J. A.: Radiative forcing of climate by changes in the vertical distribution of ozone, J. Geophys. Res., 95, 9971-9981, doi:10.1029/JD095iD07p09971, 1990.

Lin, X., Trainer, M., and Liu, S. C.: On the nonlinearity of the tropospheric ozone production, J. Geophys. Res., 93, 15879-15888, doi:10.1029/JD093iD12p15879, 1988.

Lohmann, U., Stier, P., Hoose, C., Ferrachat, S., Kloster, S., Roeckner, E., and Zhang, J.: Cloud microphysics and aerosol indirect effects in the global climate model ECHAM5-HAM, Atmos. Chem. Phys., 7, 3425-3446, doi:10.5194/acp-7-3425-2007, 2007.

Mann, G. W., Carslaw, K. S., Spracklen, D. V., Ridley, D. A., Manktelow, P. T., Chipperfield, M. P., Pickering, S. J., and Johnson, C. E.: Description and evaluation of GLOMAP-mode: a modal global aerosol microphysics model for the UKCA composition-climate model, Geosci. Model Dev., 3, 519-551, doi:10.5194/gmd-3-519-2010, 2010.

Metzger, S., Dentener, F., Pandis, S., and Lelieveld, J.: Gas/aerosol partitioning, 1, A computationally efficient model, J. Geophys. Res., 107, ACH 16-1-ACH 16-24, doi:10.1029/2001JD001102, doi:10.1029/2001JD001102, 2002.

Myhre, G., Highwood, E. J., Shine, K. P., and Stordal, F.: New estimates of radiative forcing due to well mixed greenhouse gases, Geophys. Res. Lett., 25, 2715-2718, doi:10.1029/98GL01908, 1998.

Myhre, G., Karlsdottir, S., Isaksen, I. S. A., and Stordal, F.: Radiative forcing due to changes in tropospheric ozone in the period 1980 to 1996, J. Geophys. Res., 105, 28935-28942, 2000.

Myhre, G., Bellouin, N., Berglen, T. F., Berntsen, T. K., Boucher, O., Grini, A., Isaksen, I. S. A., Johnsrud, M., Mishchenko, M. I., Stordal, F., and Tanre, D.: Comparison of the radiative properties and direct radiative effect of aerosols from a global aerosol model and remote sensing data over ocean, Tellus B, 59, 115129, 2007a.

Myhre, G., Nilsen, J. S., Gulstad, L., Shine, K. P., Rognerud, B., and Isaksen, I. S. A.: Radiative forcing due to stratospheric water vapour from $\mathrm{CH}_{4}$ oxidation, Geophys. Res. Lett., 34, L01807, doi:10.1029/2006GL027472, 2007b.

Myhre, G., Berglen, T. F., Johnsrud, M., Hoyle, C. R., Berntsen, T. K., Christopher, S. A., Fahey, D. W., Isaksen, I. S. A., Jones, T. A., Kahn, R. A., Loeb, N., Quinn, P., Remer, L., Schwarz, J. P., and Yttri, K. E.: Modelled radiative forcing of the direct aerosol effect with multi-observation evaluation, Atmos. Chem. Phys., 9, 1365-1392, doi:10.5194/acp-9-1365-2009, 2009. 
Myhre, G., Shindell, D., Bréon, F.-M.,, Collins, Fuglestvedt, J., Huang, J., Koch, J.-F. D., Lamarque, Lee, D., Mendoza, B., Nakajima, T., Robock, A., Stephens, G., Takemura, T., and Zhang, H.: Anthropogenic and Natural Radiative Forcing, in: Climate Change 2013: The Physical Science Basis, Contribution of Working Group I to the Fifth Assessment Report of the Intergovernmental Panel on Climate Change, edited by: Stocker, T. F., Qin, D., Plattner, G.-K., Tignor, M., Allen, S. K., Boschung, J., Nauels, A., Xia, Y., Bex, V., and Midgley, P. M., Cambridge University Press, Cambridge, United Kingdom and New York, NY, USA, 2013a.

Myhre, G., Samset, B. H., Schulz, M., Balkanski, Y., Bauer, S., Berntsen, T. K., Bian, H., Bellouin, N., Chin, M., Diehl, T., Easter, R. C., Feichter, J., Ghan, S. J., Hauglustaine, D., Iversen, T., Kinne, S., Kirkevåg, A., Lamarque, J.-F., Lin, G., Liu, X., Lund, M. T., Luo, G., Ma, X., van Noije, T., Penner, J. E., Rasch, P. J., Ruiz, A., Seland, Ø., Skeie, R. B., Stier, P., Takemura, T., Tsigaridis, K., Wang, P., Wang, Z., Xu, L., Yu, H., Yu, F., Yoon, J.-H., Zhang, K., Zhang, H., and Zhou, C.: Radiative forcing of the direct aerosol effect from AeroCom Phase II simulations, Atmos. Chem. Phys., 13, 1853-1877, doi:10.5194/acp-13-18532013, 2013b.

Neale, R. B., Richter, J. H., Conley, A. J., Park, S., Lauritzen, P. H., Gettelman, A., Williamson, D. L., Rasch, P. J., Vavrus, S. J., Taylor, M. A., Collins, W. D., Zhang, M., and Linn, S.-J.: Description of the NCAR Community Atmosphere Model (CAM 4.0), NCAR Technical Report, NCAR/TN-485+STR, National Center for Atmospheric Research (NCAR), Boulder, Colorado, 2010.

O’Connor, F. M., Johnson, C. E., Morgenstern, O., Abraham, N. L., Braesicke, P., Dalvi, M., Folberth, G. A., Sanderson, M. G., Telford, P. J., Voulgarakis, A., Young, P. J., Zeng, G., Collins, W. J., and Pyle, J. A.: Evaluation of the new UKCA climatecomposition model - Part 2: The Troposphere, Geosci. Model Dev., 7, 41-91, doi:10.5194/gmd-7-41-2014, 2014.

Pan, X., Chin, M., Gautam, R., Bian, H., Kim, D., Colarco, P. R., Diehl, T. L., Takemura, T., Pozzoli, L., Tsigaridis, K., Bauer, S., and Bellouin, N.: A multi-model evaluation of aerosols over South Asia: common problems and possible causes, Atmos. Chem. Phys., 15, 5903-5928, doi:10.5194/acp-15-5903-2015, 2015.

Paoli, R., Cariolle, D., and Sausen, R.: Review of effective emissions modeling and computation, Geosci. Model Dev., 4, 643667, doi:10.5194/gmd-4-643-2011, 2011.

Prather, M. J.: Time scales in atmospheric chemistry: Theory, GWPs for $\mathrm{CH} 4$ and $\mathrm{CO}$, and runaway growth, Geophys. Res. Lett., 23, 2597-2600, doi:10.1029/96GL02371, 1996.

Quaas, J., Ming, Y., Menon, S., Takemura, T., Wang, M., Penner, J. E., Gettelman, A., Lohmann, U., Bellouin, N., Boucher, O., Sayer, A. M., Thomas, G. E., McComiskey, A., Feingold, G., Hoose, C., Kristjánsson, J. E., Liu, X., Balkanski, Y., Donner, L. J., Ginoux, P. A., Stier, P., Grandey, B., Feichter, J., Sednev, I., Bauer, S. E., Koch, D., Grainger, R. G., Kirkevåg, A., Iversen, T., Seland, Ø., Easter, R., Ghan, S. J., Rasch, P. J., Morrison, H., Lamarque, J.-F., Iacono, M. J., Kinne, S., and Schulz, M.: Aerosol indirect effects - general circulation model intercomparison and evaluation with satellite data, Atmos. Chem. Phys., 9, 8697-8717, doi:10.5194/acp-9-8697-2009, 2009.
Quennehen, B., Raut, J.-C., Law, K. S., Daskalakis, N., Ancellet, G., Clerbaux, C., Kim, S.-W., Lund, M. T., Myhre, G., Olivié, D. J. L., Safieddine, S., Skeie, R. B., Thomas, J. L., Tsyro, S., Bazureau, A., Bellouin, N., Hu, M., Kanakidou, M., Klimont, Z., Kupiainen, K., Myriokefalitakis, S., Quaas, J., Rumbold, S. T., Schulz, M., Cherian, R., Shimizu, A., Wang, J., Yoon, S.-C., and Zhu, T.: Multi-model evaluation of short-lived pollutant distributions over east Asia during summer 2008, Atmos. Chem. Phys., 16, 10765-10792, doi:10.5194/acp-16-10765-2016, 2016.

Randles, C. A., Kinne, S., Myhre, G., Schulz, M., Stier, P., Fischer, J., Doppler, L., Highwood, E., Ryder, C., Harris, B., Huttunen, J., Ma, Y., Pinker, R. T., Mayer, B., Neubauer, D., Hitzenberger, R., Oreopoulos, L., Lee, D., Pitari, G., Di Genova, G., Quaas, J., Rose, F. G., Kato, S., Rumbold, S. T., Vardavas, I., Hatzianastassiou, N., Matsoukas, C., Yu, H., Zhang, F., Zhang, H., and $\mathrm{Lu}, \mathrm{P}$.: Intercomparison of shortwave radiative transfer schemes in global aerosol modeling: results from the AeroCom Radiative Transfer Experiment, Atmos. Chem. Phys., 13, 2347-2379, doi:10.5194/acp-13-2347-2013, 2013.

Riahi, K., Gruebler, A., and Nakicenovic, N.: Scenarios of longterm socio-economic and environmental development under climate stabilization, Technol. Forecast. Soc. Change, 74, 887-935, 2007.

Saleh, R., Robinson, E. S., Tkacik, D. S., Ahern, A. T., Liu, S., Aiken, A. C., Sullivan, R. C., Presto, A. A., Dubey, M. K., Yokelson, R. J., Donahue, N. M., and Robinson, A. L.: Brownness of organics in aerosols from biomass burning linked to their black carbon content, Nat.Geosci., 7, 647-650, doi:10.1038/ngeo2220, 2014.

Samset, B. H., Myhre, G., Schulz, M., Balkanski, Y., Bauer, S., Berntsen, T. K., Bian, H., Bellouin, N., Diehl, T., Easter, R. C., Ghan, S. J., Iversen, T., Kinne, S., Kirkevåg, A., Lamarque, J.F., Lin, G., Liu, X., Penner, J. E., Seland, Ø., Skeie, R. B., Stier, P., Takemura, T., Tsigaridis, K., and Zhang, K.: Black carbon vertical profiles strongly affect its radiative forcing uncertainty, Atmos. Chem. Phys., 13, 2423-2434, doi:10.5194/acp-13-24232013, 2013.

Samset, B. H., Myhre, G., Herber, A., Kondo, Y., Li, S.-M., Moteki, N., Koike, M., Oshima, N., Schwarz, J. P., Balkanski, Y., Bauer, S. E., Bellouin, N., Berntsen, T. K., Bian, H., Chin, M., Diehl, T., Easter, R. C., Ghan, S. J., Iversen, T., Kirkevåg, A., Lamarque, J.-F., Lin, G., Liu, X., Penner, J. E., Schulz, M., Seland, Ø., Skeie, R. B., Stier, P., Takemura, T., Tsigaridis, K., and Zhang, K.: Modelled black carbon radiative forcing and atmospheric lifetime in AeroCom Phase II constrained by aircraft observations, Atmos. Chem. Phys., 14, 12465-12477, doi:10.5194/acp14-12465-2014, 2014.

Schmale, J., Shindell, D., von Schneidemesser, E., Chabay, I., and Lawrence, M.: Clean up our skies, Nature, 515, 335-337, 2014.

Schulz, M., Olivié, D., Tsyro, S., Kanakidou, M., Myriokefalitakis, S., Daskalakis, N., Im, U., Fanourgakis, G., Hodnebrog, Ø., Skeie, R., Lund, M., Myhre, G., Bellouin, N., Rumbold, S., Collins, B., Cherian, R., and Quaas, J.: ECLIPSE Deliverable 2.1: Report on model accuracy, available at: http://eclipse.nilu. no/language/en-GB/ProjectOverview/Deliverables.aspx (last access: 31 October 2016), 2015.

Shindell, D.: Inhomogeneous forcing and transient climate sensitivity, Nature Climate Change, 4, 274-277, doi:10.1038/nclimate2136, 2014. 
Shindell, D. and Faluvegi, G.: Climate response to regional radiative forcing during the twentieth century, Nat. Geosci., 2, 294-300, doi:10.1038/ngeo473, 2009.

Shindell, D. T., Faluvegi, G., Koch, D. M., Schmidt, G. A., Unger, N., and Bauer, S. E.: Improved attribution of climate forcing to emissions, Science, 326, 716-718, doi:10.1126/science.1174760, 2009.

Shindell, D. T., Lamarque, J.-F., Schulz, M., Flanner, M., Jiao, C., Chin, M., Young, P. J., Lee, Y. H., Rotstayn, L., Mahowald, N., Milly, G., Faluvegi, G., Balkanski, Y., Collins, W. J., Conley, A. J., Dalsoren, S., Easter, R., Ghan, S., Horowitz, L., Liu, X., Myhre, G., Nagashima, T., Naik, V., Rumbold, S. T., Skeie, R., Sudo, K., Szopa, S., Takemura, T., Voulgarakis, A., Yoon, J.-H., and Lo, F.: Radiative forcing in the ACCMIP historical and future climate simulations, Atmos. Chem. Phys., 13, 2939-2974, doi:10.5194/acp-13-2939-2013, 2013

Shine, K. P., Fuglestvedt, J. S., Hailemariam, K., and Stuber, S.: Alternatives to the global warming potential for comparing climate impacts of emissions of greenhouse gases, Climatic Change, 68, 281-302, doi:10.1007/s10584-005-1146-9, 2005.

Skeie, R. B., Berntsen, T. K., Myhre, G., Tanaka, K., Kvalevåg, M. M., and Hoyle, C. R.: Anthropogenic radiative forcing time series from pre-industrial times until 2010, Atmos. Chem. Phys., 11, 11827-11857, doi:10.5194/acp-11-11827-2011, 2011.

Smith, S. J., Karas, J., Edmonds, J., Eom, J., and Mizrahi, A.: Sensitivity of multi-gas climate policy to emission metrics, Climatic Change, 117, 663-675, doi:10.1007/s10584-012-0565-7, 2013.

Stevens, B. and Feingold, G.: Untangling aerosol effects on clouds and precipitation in a buffered system, Nature, 461, 607-613, doi:10.1038/nature08281, 2009.

Stevens, B., Giorgetta, M., Esch, M., Mauritsen, T., Crueger, T., Rast, S., Salzmann, M., Schmidt, H., Bader, J., Block, K., Brokopf, R., Fast, I., Kinne, S., Kornblueh, L., Lohmann, U., Pincus, R., Reichler, T., and Roeckner, E.: Atmospheric component of the MPI-M Earth System Model: ECHAM6, J. Adv. Model. Earth Syst., 5, 146-172, 2013.

Stevenson, D. S., Young, P. J., Naik, V., Lamarque, J.-F., Shindell, D. T., Voulgarakis, A., Skeie, R. B., Dalsoren, S. B., Myhre, G., Berntsen, T. K., Folberth, G. A., Rumbold, S. T., Collins, W. J., MacKenzie, I. A., Doherty, R. M., Zeng, G., van Noije, T. P. C., Strunk, A., Bergmann, D., Cameron-Smith, P., Plummer, D. A., Strode, S. A., Horowitz, L., Lee, Y. H., Szopa, S., Sudo, K., Nagashima, T., Josse, B., Cionni, I., Righi, M., Eyring, V., Conley, A., Bowman, K. W., Wild, O., and Archibald, A.: Tropospheric ozone changes, radiative forcing and attribution to emissions in the Atmospheric Chemistry and Climate Model Intercomparison Project (ACCMIP), Atmos. Chem. Phys., 13, 3063-3085, doi:10.5194/acp-13-3063-2013, 2013.

Stier, P., Feichter, J., Kinne, S., Kloster, S., Vignati, E., Wilson, J., Ganzeveld, L., Tegen, I., Werner, M., Balkanski, Y., Schulz, M., Boucher, O., Minikin, A., and Petzold, A.: The aerosol-climate model ECHAM5-HAM, Atmos. Chem. Phys., 5, 1125-1156, doi:10.5194/acp-5-1125-2005, 2005.

Stier, P., Schutgens, N. A. J., Bellouin, N., Bian, H., Boucher, O., Chin, M., Ghan, S., Huneeus, N., Kinne, S., Lin, G., Ma, X., Myhre, G., Penner, J. E., Randles, C. A., Samset, B., Schulz, M., Takemura, T., Yu, F., Yu, H., and Zhou, C.: Host model uncertainties in aerosol radiative forcing estimates: results from the Aero-
Com Prescribed intercomparison study, Atmos. Chem. Phys., 13, 3245-3270, doi:10.5194/acp-13-3245-2013, 2013.

Stohl, A., Aamaas, B., Amann, M., Baker, L. H., Bellouin, N., Berntsen, T. K., Boucher, O., Cherian, R., Collins, W., Daskalakis, N., Dusinska, M., Eckhardt, S., Fuglestvedt, J. S., Harju, M., Heyes, C., Hodnebrog, Ø., Hao, J., Im, U., Kanakidou, M., Klimont, Z., Kupiainen, K., Law, K. S., Lund, M. T., Maas, R., MacIntosh, C. R., Myhre, G., Myriokefalitakis, S., Olivié, D., Quaas, J., Quennehen, B., Raut, J.-C., Rumbold, S. T., Samset, B. H., Schulz, M., Seland, Ø., Shine, K. P., Skeie, R. B., Wang, S., Yttri, K. E., and Zhu, T.: Evaluating the climate and air quality impacts of short-lived pollutants, Atmos. Chem. Phys., 15, 10529-10566, doi:10.5194/acp-15-10529-2015, 2015.

Streets, D. G., Bond, T. C., Carmichael, G. R., Fernandes, S. D., Fu, Q., He, D., Klimont, Z., Nelson, S. M., Tsai, N. Y., Wang, M. Q., Woo, J.-H., and Yarber, K. F.: An inventory of gaseous and primary aerosol emissions in Asia in the year 2000, J. Geophys. Res., 108, 8809, doi:10.1029/2002JD003093, D21, 2003.

Taylor, J. P. and McHaffie, A.: Measurements of cloud susceptibility, J. Atmos. Sci., 51, 10, 1298-1306, 1994.

Tsigaridis, K., Daskalakis, N., Kanakidou, M., Adams, P. J., Artaxo, P., Bahadur, R., Balkanski, Y., Bauer, S. E., Bellouin, N., Benedetti, A., Bergman, T., Berntsen, T. K., Beukes, J. P., Bian, H., Carslaw, K. S., Chin, M., Curci, G., Diehl, T., Easter, R. C., Ghan, S. J., Gong, S. L., Hodzic, A., Hoyle, C. R., Iversen, T., Jathar, S., Jimenez, J. L., Kaiser, J. W., Kirkevåg, A., Koch, D., Kokkola, H., Lee, Y. H., Lin, G., Liu, X., Luo, G., Ma, X., Mann, G. W., Mihalopoulos, N., Morcrette, J.-J., Müller, J.-F., Myhre, G., Myriokefalitakis, S., Ng, N. L., O’Donnell, D., Penner, J. E., Pozzoli, L., Pringle, K. J., Russell, L. M., Schulz, M., Sciare, J., Seland, Ø., Shindell, D. T., Sillman, S., Skeie, R. B., Spracklen, D., Stavrakou, T., Steenrod, S. D., Takemura, T., Tiitta, P., Tilmes, S., Tost, H., van Noije, T., van Zyl, P. G., von Salzen, K., Yu, F., Wang, Z., Wang, Z., Zaveri, R. A., Zhang, H., Zhang, K., Zhang, Q., and Zhang, X.: The AeroCom evaluation and intercomparison of organic aerosol in global models, Atmos. Chem. Phys., 14, 10845-10895, doi:10.5194/acp-1410845-2014, 2014.

Viana, M., Hammingh, P., Colette, A., Querol, X., Degraeuwe, B., de Vlieger, I., and van Aardenne, J.: Impact of maritime transport emissions on coastal air quality in Europe, Atmos. Environ., 90, 96-105, doi:10.1016/j.atmosenv.2014.03.046, 2014.

Vignati, E., Wilson, J., and Stier, P.: M7: an efficient sizeresolved aerosol microphysics module for large-scale aerosol transport models, J. Geophys. Res., 109, D22202, doi:10.1029/2003JD004485, 2004.

von Schneidemesser, E., Monks, P. S., Allan, J. D., Bruhwiler, L., Forster, P., Fowler, D., Lauer, A., Morgan, W. T., Paasonen, P., Righi, M., Sindelarova, K., and Sutton, M. A.: Chemistry and the linkages between air quality and climate change, Chem. Rev., 115, 3856-3897, 2015.

Voulgarakis, A., Naik, V., Lamarque, J.-F., Shindell, D. T., Young, P. J., Prather, M. J., Wild, O., Field, R. D., Bergmann, D., CameronSmith, P., Cionni, I., Collins, W. J., Dalsøren, S. B., Doherty, R. M., Eyring, V., Faluvegi, G., Folberth, G. A., Horowitz, L. W., Josse, B., MacKenzie, I. A., Nagashima, T., Plummer, D. A., Righi, M., Rumbold, S. T., Stevenson, D. S., Strode, S. A., Sudo, K., Szopa, S., and Zeng, G.: Analysis of present day and future $\mathrm{OH}$ and methane lifetime in the ACCMIP simulations, 
Atmos. Chem. Phys., 13, 2563-2587, doi:10.5194/acp-13-25632013, 2013.

Wang, R., Balkanski, Y., Boucher, O., Ciais, P., Schuster, G. L., Chevallier, F., Samset, B. H., Liu, J., Piao, S., Valari, M., and Tao, S.: Estimation of global black carbon direct radiative forcing and its uncertainty constrained by observations, J. Geophys. Res.Atmos., 121, 5948-5971, doi:10.1002/2015JD024326, 2016.

Wang, X., Heald, C. L., Ridley, D. A., Schwarz, J. P., Spackman, J. R., Perring, A. E., Coe, H., Liu, D., and Clarke, A. D.: Exploiting simultaneous observational constraints on mass and absorption to estimate the global direct radiative forcing of black carbon and brown carbon, Atmos. Chem. Phys., 14, 10989-11010, doi:10.5194/acp-14-10989-2014, 2014a.

Wang, Q. Q., Jacob, D. J., Spackman, J. R., Perring, A. R., Schwartz, J. P., Moteki, N., Marais, E. A., Ge, C., Wang, J., and Barrett, S. R. H.: Global budget and radiative forcing of black carbon aerosol: Constraints from pole-to-pole (HIPPO) observations across the Pacific, J. Geophys. Res., 119, 195-206, doi:10.1002/2013JD020824, 2014b.

Wilcox, E. M.: Stratocumulus cloud thickening beneath layers of absorbing smoke aerosol, Atmos. Chem. Phys., 10, 1176911777, doi:10.5194/acp-10-11769-2010, 2010.

Wilcox, L. J., Highwood, E. J., Booth, B. B. B., and Carslaw, K. S.: Quantifying sources of inter-model diversity in the cloud albedo effect. Geophys. Res. Lett., 42, 1568-1575, doi:10.1002/2015GL063301, 2015.

WMO: Scientific Assessment of Ozone Depletion: 2014, Global Ozone Research and Monitoring Project - Report No. 55, World Meteorological Organization, Geneva, Switzerland, 2014.
Young, P. J., Archibald, A. T., Bowman, K. W., Lamarque, J.-F., Naik, V., Stevenson, D. S., Tilmes, S., Voulgarakis, A., Wild, O., Bergmann, D., Cameron-Smith, P., Cionni, I., Collins, W. J., Dalsøren, S. B., Doherty, R. M., Eyring, V., Faluvegi, G., Horowitz, L. W., Josse, B., Lee, Y. H., MacKenzie, I. A., Nagashima, T., Plummer, D. A., Righi, M., Rumbold, S. T., Skeie, R. B., Shindell, D. T., Strode, S. A., Sudo, K., Szopa, S., and Zeng, G.: Preindustrial to end 21st century projections of tropospheric ozone from the Atmospheric Chemistry and Climate Model Intercomparison Project (ACCMIP), Atmos. Chem. Phys., 13, 20632090, doi:10.5194/acp-13-2063-2013, 2013.

Yu, H., Chin, M., West, J. J., Atherton, C. S., Bellouin, N., Bergmann, D., Bey, I., Bian, H., Diehl, T., Forberth, G., Hess, P., Schulz, M., Shindell, D., Takemura, T., and Tan, Q.: A multimodel assessment of the influence of regional anthropogenic emission reductions on aerosol direct radiative forcing and the role of intercontinental transport, J. Geophys. Res., 118, 700 720, doi:10.1029/2012JD018148, 2013.

Zhang, K., O'Donnell, D., Kazil, J., Stier, P., Kinne, S., Lohmann, U., Ferrachat, S., Croft, B., Quaas, J., Wan, H., Rast, S., and Feichter, J.: The global aerosol-climate model ECHAM-HAM, version 2: sensitivity to improvements in process representations, Atmos. Chem. Phys., 12, 8911-8949, doi:10.5194/acp-12-89112012, 2012. 